\title{
Production, milk fatty acid profile, and nutrient utilization in grazing dairy cows supplemented with ground flaxseed
}

\author{
B. J. Isenberg, ${ }^{1 *}$ K. J. Soder, ${ }^{2}$ A. B. D. Pereira, ${ }^{1} \dagger$ R. Standish, ${ }^{1} \ddagger$ and A. F. Brito ${ }^{1} \S$ \\ ${ }^{1}$ Department of Agriculture, Nutrition, and Food Systems, University of New Hampshire, Durham 03824 \\ ${ }^{2}$ Pasture Systems and Watershed Management Research Unit, USDA-Agricultural Research Service, University Park, PA 16802
}

\section{ABSTRACT}

Flaxseed has been extensively used as a supplement for dairy cows because of its high concentrations of energy and the n-3 fatty acid (FA) cis-9,cis-12,cis-15 18:3. However, limited information is available regarding the effect of ground flaxseed on dry matter intake (DMI), ruminal fermentation, and nutrient utilization in grazing dairy cows. Twenty multiparous Jersey cows averaging (mean \pm standard deviation) $111 \pm 49 \mathrm{~d}$ in milk in the beginning of the study were used in a randomized complete block design to investigate the effects of supplementing herbage (i.e., grazed forage) with ground corn-soybean meal mix (control diet = CTRL) or ground flaxseed (flaxseed diet $=$ FLX) on animal production, milk FA, ruminal metabolism, and nutrient digestibility. The study was conducted from June to September 2013, with data and sample collection taking place on wk 4, 8, 12, and 16 . Cows were fed a diet formulated to yield a 60:40 forage-to-concentrate ratio consisting of (dry matter basis): $40 \%$ cool-season perennial herbage, $50 \%$ partial total mixed ration, and $10 \%$ of ground corn-soybean meal mix or $10 \%$ ground flaxseed. However, estimated herbage DMI averaged $5.59 \mathrm{~kg} / \mathrm{d}$ or $34 \%$ of the total DMI. Significant treatment by week interactions were observed for milk and blood urea N, and several milk FA (e.g., trans-10 18:1). No significant differences between treatments were observed for herbage and total DMI, milk yield, feed efficiency, concentrations and yields of milk components, and urinary excretion of purine derivatives. Total-tract digestibility of organic matter decreased, whereas that of neutral detergent fiber increased with feeding FLX versus CTRL. No treatment effects were observed for ruminal concentrations of total volatile $\mathrm{FA}$ and $\mathrm{NH}_{3^{-}}$ $\mathrm{N}$, and ruminal proportions of acetate and propionate.

Received July 12, 2018.

Accepted November 1, 2018.

*Present address: Brown's Feeds, Birdsboro, PA 19508.

$\dagger$ Present address: Adisseo USA Inc., Alpharetta, GA 30022.

$\ddagger$ Present address: Poulin Grain, Newport, VT 05855.

$\S$ Corresponding author: andre.brito@unh.edu
Ruminal butyrate tended to decrease, and the acetateto-propionate ratio decreased in the FLX diet. Most saturated and unsaturated FA in milk fat were changed. Specifically, milk proportion of cis-9,cis-12,cis-15 18:3, $\Sigma \mathrm{n}-3 \mathrm{FA}$, and $\Sigma 18 \mathrm{C}$ FA increased, whereas that of cis9,cis-12 18:2, $\Sigma$ n-6 FA, $\Sigma$ odd-chain FA, $\Sigma<16 \mathrm{C}$ FA, and $\Sigma 16 \mathrm{C}$ FA decreased with feeding FLX versus the CTRL diet. In conclusion, feeding FLX did not change yields of milk and milk components, but increased milk n-3 FA. Therefore, costs and industry adoption of premiums for n-3-enriched milk will determine the adoption of ground flaxseed in pasture-based dairy farms. Key words: $\alpha$-linolenic acid, energy supplementation, milk yield, pasture

\section{INTRODUCTION}

Flaxseed (Linum usitatissimum L.) has been extensively used as a supplement for dairy cows because of its high concentrations of energy and n-3 fatty acids (FA), particularly cis-9, cis-12,cis-15 18:3 (i.e., $\alpha$-linolenic acid $=$ ALA; Petit, 2010). Milk n-3 FA and cis-9,trans-11 18:2 increased when dairy cows were fed different forms of flaxseed, including ground (GFLX; Resende et al., 2015), crushed (Sterk et al., 2011), whole (Petit and Côrtes, 2010), or extruded (Ferlay et al., 2013). Previous research showed a variety of human health benefits attributed to n-3 FA and cis-9,trans-11 18:2 such as modulation of immune and inflammatory responses, improved brain and vision development, and prevention of cardiovascular diseases and cancer (Connor, 2000; Williams, 2000; McCrorie et al., 2011; Dilzer and Park, 2012). A 2-yr survey conducted by Cargill with more than 500 US consumers responsible for purchasing household groceries revealed that $98 \%$ of the participants were aware of n-3 FA and more inclined to buy products containing ALA, eicosapentaenoic acid, and docosahexaenoic acid (Cargill, 2014). Eighty-four percent of organic dairy farmers who responded to a survey $(\mathrm{n}=183)$ conducted in the northeastern United States identified the need for developing new marketing venues for value-added dairy products (Pereira et al., 
2013). There is a growing demand in the United States for "grass-fed" milk naturally enriched with bioactive FA (Benbrook et al., 2018). Supplementation of herbage (i.e., grazed forage) with GFLX may further improve n-3 FA and cis-9,trans-11 18:2 in milk fat because of the high concentration of ALA in both herbage (Brito et al., 2017) and GFLX (Resende et al., 2015; Hafla et al., 2018).

Limited energy supply impairs milk yield in grazing dairy cows (Kolver and Muller, 1998; Bargo et al., 2003; Hafla et al., 2016). Ground flaxseed is an energydense feed that can be used to increase $\mathrm{NE}_{\mathrm{L}}$ supply in herbage-based diets. However, information is scarce regarding the effect of GFLX on DMI, yields of milk and milk components, milk FA profile, and nutrient digestibility in grazing dairy cows. We showed that apparent digestibilities of OM and NDF decreased linearly, whereas flow of microbial $\mathrm{N}$ did not change in continuous culture fermentors dosed with orchardgrass herbage and incremental amounts of GFLX $(0,5,10$, or $15 \%$ of the diet DM; Soder et al., 2012). In a subsequent study, we observed that yields of milk and milk components decreased linearly in dairy cows offered grass-legume baleage supplemented with GFLX at $0,5,10$, or $15 \%$ of the diet DM (Resende et al., 2015). Collectively, our in vitro (Soder et al., 2012) and in vivo (Resende et al., 2015) data showed that the greatest dietary inclusion of GFLX ( $15 \%$ of the diet DM) led to the lowest milk yield and nutrient digestibility. In contrast, 10\% GFLX either maintained or slightly depressed in vitro digestibility of nutrients (Soder et al., 2012) or milk yield (Resende et al., 2015) compared with 0\% GFLX, and improved milk n-3 FA and cis-9,trans-11 18:2 (Resende et al., 2015).

The objective of the present study was to investigate the effects of herbage supplementation (10\% of the diet DM) with a ground corn-soybean meal (GRCSBM) mix versus GFLX top-dressed to a partial TMR (pTMR) on animal production, milk FA profile, ruminal metabolism, and nutrient utilization in Jersey cows during the grazing season. We hypothesized that yields of milk and milk components would increase due to enhanced energy supply via supplementation of GFLX (flaxseed diet $=\mathbf{F L X}$ ) compared with GRC-SBM mix (control diet $=\mathbf{C T R L})$. We also hypothesized that the concentrations of milk n-3 FA and cis-9,trans-11 18:2 would improve in response to increased intake of ALA in cows fed FLX versus the CTRL diet.

\section{MATERIALS AND METHODS}

All procedures related to animal care were approved by the University of New Hampshire Institutional Animal Care and Use Committee (protocol no. 110605).
The experiment was conducted from June 8 to September 27, 2013, at the University of New Hampshire Burley-Demeritt Organic Dairy Research Farm (Lee, $\left.\mathrm{NH} ; 43^{\circ} 10^{\prime} \mathrm{N}, 70^{\circ} 99^{\prime} \mathrm{W}\right)$. Environmental temperature $\left(\right.$ minimum $=2.3^{\circ} \mathrm{C} ;$ maximum $=34.2^{\circ} \mathrm{C} ;$ average $=$ $19.1^{\circ} \mathrm{C}$ ) and relativity humidity (minimum $=27.4 \%$; maximum $=100 \%$; average $=78.9 \%$ ) during the study were determined by hourly daily data from the National Climate Data Center weather station at the University of New Hampshire Kingman Farm (Durham, NH; $43^{\circ} 17^{\prime} \mathrm{N}, 70^{\circ} 93^{\prime} \mathrm{W}$ ) located approximately $12 \mathrm{~km}$ away from the experimental site.

\section{Cows, Experimental Design, and Treatments}

Twenty multiparous, organically certified Jersey cows averaging (mean $\pm \mathrm{SD}) 111 \pm 49 \mathrm{DIM}, 16.4 \pm 2.89 \mathrm{~kg} / \mathrm{d}$ of milk, $2.75 \pm 1.29$ lactations, and $414 \pm 32 \mathrm{~kg}$ of BW in the beginning of the study were used in a randomized complete block design. Cows were blocked in pairs ( $\mathrm{n}=10$ pairs) according to DIM and milk yield and, within pairs, randomly assigned to treatments. Diets were formulated and evaluated using the NRC (2001) and consisted of (DM basis): $40 \%$ cool-season perennial herbage, $50 \%$ pTMR, and $10 \%$ of a $61: 39$ GRC-SBM mix or $10 \%$ GFLX. However, the actual proportion of herbage in the diet DM estimated using $\mathrm{Cr}_{2} \mathrm{O}_{3}$ and indigestible ADF (iADF) averaged (DM basis) $34 \%$ (see Calculations and Results and Discussion below). The GRC-SBM mix (CTRL diet) or GFLX (FLX diet) was top-dressed to the pTMR, which contained (DM basis): $50 \%$ first-cut mixed-mostly grass baleage, $46.3 \%$ concentrate blend, and $3.7 \%$ sugarcane liquid molasses. Animals assigned to the CTRL diet averaged (mean \pm $\mathrm{SD}$ ), in the beginning of the study, $107 \pm 53$ DIM, 2.70 \pm 1.34 lactations, $16.2 \pm 2.41 \mathrm{~kg}$ of milk/d, and $402 \pm$ $32 \mathrm{~kg}$ of BW, whereas those assigned to the FLX diet averaged $116 \pm 40$ DIM, $2.80 \pm 1.32$ lactations, $16.6 \pm$ $2.46 \mathrm{~kg}$ of milk/d, and $427 \pm 28 \mathrm{~kg}$ of BW. The study was conducted throughout the grazing season (112 d total), with data and sample collection taking place on wk 4 (June 29 to July 5), wk 8 (July 27 to August 2), wk 12 (August 24 to 30), and wk 16 (September 21 to 27). Cows had free access to water for the duration of the study. A 2-wk covariate period in which cows grazed cool-season perennial herbage supplemented with pTMR was used to control for animal-to-animal variation. Milk yield was recorded daily throughout the 2-wk covariate period, with samples of milk, blood, urine, and ruminal fluid collected once during d 13 to 15. Body weight (d 13 to 15 ) and BCS (d 15) were also recoded.

Mixed-mostly grass baleage used in the pTMR was harvested and preserved in plastic-wrapped bales as 
previously described (Resende et al., 2015). Whole grain flaxseed, which was finely ground via a proprietary cold milling process, was obtained from AgMotion Inc. (Minneapolis, MN). Diets were formulated to be isonitrogenous (DM basis) by adjusting the proportion of GRC and SBM in the GRC-SBM mix relative to the concentration of CP in GFLX.

\section{Management of Cows and Feeding}

Cows were milked twice daily at approximately 0615 and $1715 \mathrm{~h}$ and milk weights were recorded throughout the experiment. Housing of cows after milking, access to pasture, and strip grazing management followed similar procedures reported by Brito et al. (2017). The pTMR was prepared fresh at approximately $1700 \mathrm{~h}$ with enough amount to last for 2 feeding events (afternoon of the same day and the next morning) using a vertical mixer (V-Mix 400, ValMetal, Tomah, WI). The GRC-SBM mix or GFLX was top-dressed to the pTMR twice daily at 0630 and $1730 \mathrm{~h}$ with orts weighed at 1500 h. Supplement feeding (pTMR plus grains) was individualized using electronic recognition Calan doors (American Calan Inc., Northwood, NH). During each 7-d sampling collection week, cows assigned to the study grazed separately from the remaining lactating animals in adjacent paddocks. Cows had approximately $16.5 \mathrm{~h}$ of access to pasture daily. Animals were weighed for 3 consecutive days before the beginning of the experiment and during the last $3 \mathrm{~d}$ of wk $4,8,12$, and 16 to calculate daily BW change. Three independent individuals assigned BCS at the beginning of the experiment and in the last $3 \mathrm{~d}$ of each of the 4 sampling weeks using a 1 to 5 scale (Wildman et al., 1982) to determine period (monthly) BCS change.

Chromium sequisoxide $\left(\mathrm{Cr}_{2} \mathrm{O}_{3}\right.$, City Chemical LCC, West Haven, CT) was incorporated by Morrison's Custom Feeds (Barnet, VT) into a pelleted feed and used as an external marker to estimate fecal output of DM. A comparable portion of the concentrate blend used in the pTMR was substituted (DM basis) with $834 \mathrm{~g} / \mathrm{d}$ of the $\mathrm{Cr}_{2} \mathrm{O}_{3}$-containing pellet (split in 2 feedings) of similar ingredient composition. This pellet was offered immediately before the morning and afternoon feedings of pTMR for $10 \mathrm{~d}$ (d 18-28, d 46-56, d 74-84, and d 102-112) in rubber pans placed inside the Calan doors (American Calan Inc.) to ensure complete consumption, which was confirmed visually. Concentration of $\mathrm{Cr}$ in the pellet averaged (mean $\pm \mathrm{SD}$ ) $7,063 \pm 483 \mathrm{mg} / \mathrm{kg}$, with estimated daily $\mathrm{Cr}$ intake of $5.91 \mathrm{~g} /$ cow.

Cows had access to a portable head-chamber unit mounted in a trailer and equipped with solar panels (GreenFeed, C-Lock Inc., Rapid City, SD) for gaseous measurements $\left(\mathrm{CH}_{4}\right.$ and $\mathrm{CO}_{2}$; data not shown $)$ throughout the experiment and consumed (mean \pm SD) $382 \pm 214 \mathrm{~g} / \mathrm{d}$ of alfalfa pellet (DM basis) during the sampling collection weeks. Alfalfa pellet was used as a bait to attract cows to the GreenFeed unit resulting in 442 visits by 18 animals at wk 4, 8, 12, and 16 .

\section{Feed Sampling and Analyses}

Herbage samples were collected each time cows were moved to a new strip of fresh pasture during the sampling collection weeks. For determination of pre- and postgrazing herbage biomass ( $\mathrm{kg}$ of DM/ha) and sward botanical composition, herbage samples were collected by cutting to ground level forage enclosed in a $0.25-\mathrm{m}^{2}$ quadrat using hand shears. Quadrats were thrown 20 times in a zig-zag pattern in each paddock. Pasture paddocks were mapped using a global positioning system device (Garmin Ltd., Olathe, KS), with 1 to $2 \mathrm{~m}$ range accuracy, to record the area $\left(\mathrm{m}^{2}\right)$ to be grazed. Samples for nutritive value analysis were collected using the hand-plucking method of Kolver and Muller (1998) by harvesting herbage inside the frame of a $0.25-\mathrm{m}^{2}$ quadrat to a height equivalent to that of postgrazing, with quadrats placed adjacent to pregrazing sampling spots. Herbage for botanical composition samples were sorted into 4 categories: (1) grasses, (2) legumes, (3) weeds, and (4) dead materials. All samples were dried at $55^{\circ} \mathrm{C}$ in a forced-air oven (VWR Scientific, Bridgeport, NJ) for approximately $48 \mathrm{~h}$.

Concentrate blend, GRC-SBM mix, GFLX, and $\mathrm{Cr}_{2} \mathrm{O}_{3}$-containing pellet samples were collected once during each of the 4 sampling weeks for nutrient analyses. Three samples of liquid molasses (1/tote) and 2 samples of alfalfa pellet (1/batch) were collected during the experiment. All bales fed in the experiment were sampled ( 200 g/bale) using an electric drill (model TE 7-A, Hilti Inc., Tulsa, OK) fitted with a 45-cm stainless steel core sampler barrel (Nasco, Fort Atkinson, WI). Samples of pTMR and orts were collected daily during each sampling collection week. Feed and ort samples were dried for $48 \mathrm{~h}$ in a forced-air oven (VWR International) at $55^{\circ} \mathrm{C}$, with baleage DM used to adjust the daily proportion of baleage in the pTMR. Dried baleage, concentrates, pTMR, orts, and herbage samples were ground to pass through a $1-\mathrm{mm}$ screen using a Wiley mill (Thomas Scientific, Swedesboro, NJ). Daily samples of herbage, baleage, pTMR, and orts (by treatment) were composited across each sampling collection week.

Herbage, pTMR, GRC-SBM mix, GFLX, and $\mathrm{Cr}_{2} \mathrm{O}_{3^{-}}$ containing pellets were analyzed by a commercial laboratory (Analab, Fulton, IL) according to AOAC (1990) methods as follows: absolute DM (method 935.29), CP (method 990.03), NDF (method 2002.04 
using $\alpha$-amylase and sodium sulfite), ADF (method 973.18), ether extract (method 920.39), ash (method 942.05), Ca, P, Mg, K, Fe, Zn, Cu, Mn (method 985.01 by inductively coupled plasma spectroscopy), and $\mathrm{S}$ (method 923.01). Chromium was determined via atomic absorption (Williams et al., 1962; Binnerts et al., 1968). Samples of baleage, concentrate blend, orts, and alfalfa pellets were analyzed for absolute DM, CP, NDF, ADF, and ash following the AOAC (1990) methods outlined above at Analab. Baleage samples were further analyzed for soluble protein (Licitra et al., 1996), neutral detergent insoluble CP [methods 2002.04 (without sodium sulfite) and 976.06; AOAC, 1990], acid detergent insoluble CP (methods 973.18 and 976.06; AOAC, 1990), and ADL (method 973.18; AOAC, 1990). Liquid molasses was analyzed for CP, ether extract, and ash as reported above, and for individual sugars using a Beckman HPLC (Beckman Coulter Inc., Fullerton, CA) equipped with an evaporative light scattering detection system by Analab.

Herbage, pTMR, GRC-SBM mix, and GFLX samples were shipped to The Pennsylvania State University (University Park; Kevin Harvatine laboratory) for FA analysis using GLC after direct methylation (Sukhija and Palmquist, 1988). For determination of iADF (Huhtanen et al., 1994), approximately $0.5 \mathrm{~g}$ of dried and ground (1-mm screen; Willey mill) samples of herbage, pTMR, all concentrate feeds, and feces were weighed into Ankom F57 bags (Ankom Technology, Macedon, NY), placed in 1 larger nylon laundry bag, and inserted in the rumen of 1 multiparous ruminally cannulated lactating Holstein cow fed a corn silagegrass haylage-based TMR (52:48 forage to concentrate ratio). After 12 d of incubation, bags were removed from the rumen, rinsed with tap water, and analyzed for ADF (Ankom Technology method 5; solutions as in method 973.18; AOAC, 1990).

\section{Milk Sampling and Analyses}

Milk samples were collected during 4 consecutive milkings starting in the afternoon milking of $d 1$ of each sampling collection week and finishing in the morning milking of d 3. Samples were composited (2 sets each of afternoon and morning milkings) based on individual milk yield, preserved with a 2-bromo-2-nitropropan-1,3 diol tablet (D\&F Control Systems Inc., Norwood, MA), and refrigerated at $4^{\circ} \mathrm{C}$ until analyses. Composite milk samples were shipped to Dairy One Cooperative Inc. (Ithaca, NY) and analyzed for concentrations of fat, true protein, lactose, SNF, TS, and MUN by Fourier transform infrared spectroscopy using a MilkoScan model FT+ (Foss Inc., Hillerød, Denmark), and SCC by flow cytometry with a Fossomatic FC (Foss Inc.).
Milk composites without preservative from all 4 milkings were stored at $-80^{\circ} \mathrm{C}$ for later analysis of $\mathrm{FA}$ at The Pennsylvania State University (Kevin Harvatine laboratory) using GLC according to Rico and Harvatine (2013).

\section{Blood Sampling and Analyses}

Blood was sampled via the coccygeal vein or artery twice daily approximately at 0515 and $1500 \mathrm{~h}$ during the first $2 \mathrm{~d}$ of each sampling collection week. Samples were taken in 10-mL evacuated-glycerin coated red stopper tubes (Monoject, Covidien, Mansfield, MA) with a 20-gauge needle (Monoject), allowed to clot at room temperature for up to $2 \mathrm{~h}$, and centrifuged for $20 \mathrm{~min}$ at $1,200 \times g$ at $4^{\circ} \mathrm{C}$. Serum was collected and pooled in equal amounts across sampling times to capture potential variation encompassed during the feeding cycle between pre- and postsupplementation of pTMR plus grains, and access to pasture between morning and afternoon milkings. Composited samples for serum cortisol analysis were stored at $-80^{\circ} \mathrm{C}$, whereas those used for serum FA and BUN were kept at $-20^{\circ} \mathrm{C}$ until analyses. An ELISA kit (BioVendor LLC, Asheville, $\mathrm{NC}$ ) was used to measure serum cortisol concentration. Analysis of serum concentration of FA was performed using a Wako HR Series NEFA-HR(2) kit (Wako Chemicals USA Inc., Richmond, VA). A chromate microplate (Awareness Technology Inc., Palm City, FL) was used to read absorbance of both FA $(550 \mathrm{~nm})$ and cortisol $(450 \mathrm{~nm})$ assays. Blood urea $\mathrm{N}$ was determined colorimetrically by a UV/visible spectrophotometer (Beckman Coulter Inc., Brea, CA) set at a wavelength of 540 $\mathrm{nm}$ using the diacetyl-monoxime method (Rosenthal, 1955).

\section{Ruminal Sampling and Analyses}

Ruminal fluid samples were collected 3 times from 10 cows ( $\mathrm{n}=5 /$ treatment) after the morning milking ( $\sim 0700 \mathrm{~h})$ during d 4 to 6 of each sampling collection week using the stomach tube method described by Lodge-Ivey et al. (2009). Cows were restrained in a head chute (Zimmerman, PBZ LLC, Lititz, PA) with belly straps to discourage movement and facilitate sample collection. The initial 200- to $400-\mathrm{mL}$ portion of the sample was discarded to minimize saliva contamination. Next, a $40-\mathrm{mL}$ aliquot of strained ruminal fluid was added to $2.4 \mathrm{~mL}$ of $6 \mathrm{~N} \mathrm{HCl}$ and stored at $-20^{\circ} \mathrm{C}$ for later analysis of $\mathrm{NH}_{3}-\mathrm{N}$ as reported in Pereira et al. (2017). A second 40-mL aliquot of strained ruminal fluid was added to $0.18 \mathrm{~mL}$ of $50 \% \mathrm{H}_{2} \mathrm{SO}_{4}$ ( $\mathrm{vol} / \mathrm{vol}$ ) and stored at $-20^{\circ} \mathrm{C}$ until VFA analyses at the West Virginia Rumen Fermentation Profiling Laboratory 
(Morgantown, WV) using a GC instrument (Varian 3300, Varian Inc., Palo Alto, CA) equipped with a flame ionization detector.

\section{Urine and Fecal Sampling and Analyses}

Spot urine samples were collected twice daily at approximately 0515 and $1500 \mathrm{~h}$ for 3 consecutive days (d 3 to 5 of each sampling week) during voluntary urination or through stimulation of the pudendal nerve by massaging the area below the vulva. Samples were composited to create 1 sample/cow over $3 \mathrm{~d}$ by mixing $8 \mathrm{~mL}$ of urine and $400 \mu \mathrm{L}$ of $6 \mathrm{~N} \mathrm{HCl}$ per time collection point. Composited samples were stored at $-20^{\circ} \mathrm{C}$ until later analyses of nitrogenous metabolites. After thawing at room temperature, samples were analyzed colorimetrically for concentrations of creatinine (assay kit no. 500701, Cayman Chemical Co., Ann Arbor, MI) using a chromate microplate reader set at a wavelength of $492 \mathrm{~nm}$ (Awareness Technology Inc.), allantoin (Chen et al., 1992), uric acid (assay kit no. 1045-225, Stanbio Laboratory, Boerne, TX), and total N (microKjeldahl, Dairy One Cooperative Inc.). Allantoin and uric acid were read at wavelengths of 522 and $520 \mathrm{~nm}$, respectively, on a UV/visible spectrophotometer (Beckman Coulter Inc.).

Fecal samples were collected twice daily at approximately 0515 and $1500 \mathrm{~h}$ during the last $5 \mathrm{~d}$ of each sampling collection week during voluntary defecation or by rectal grab. Samples were pooled by cow, dried in a forced-air oven (Sheldon Manufacturing Inc., Cornelius, OR) at $55^{\circ} \mathrm{C}$ for approximately $72 \mathrm{~h}$, and ground to pass through a 1-mm screen using a Wiley mill (Thomas Scientific) until analyzed for absolute DM, $\mathrm{CP}, \mathrm{ADF}, \mathrm{NDF}$, ash, and Cr by Analab as reported for feedstuffs above.

\section{Calculations}

Pre- and postgrazing herbage mass were calculated by multiplying the amount of forage within the quadrat frame by the total paddock area (ha). Herbage allowance was calculated by multiplying pregrazing herbage mass $(\mathrm{kg}$ of $\mathrm{DM} / \mathrm{ha})$ times the daily pasture area $\left(\mathrm{m}^{2}\right)$ allocated to individual cows divided by 10,000 to convert from meters ${ }^{2}$ to hectares. Herbage intake was determined according to Hellwing et al. (2015) as follows:

estimated herbage DMI $(\mathrm{kg} / \mathrm{d})=$

$\{$ fecal output $(\mathrm{kg} / \mathrm{d}) \times$ fecal iADF $(\mathrm{g} / \mathrm{kg}$ of DM) $]$

- total supplement iADF (g/d)\}/

herbage iADF (g/kg of DM), where total supplement iADF refers to the iADF intake of pTMR, GRC-SBM mix, GFLX, $\mathrm{Cr}_{2} \mathrm{O}_{3}$-containing pellet, and alfalfa pellet. Chromium concentration in feces was used as an external marker to estimate fecal output of DM according to Kolver and Muller (1998):

$$
\begin{aligned}
& \text { fecal output of DM }(\mathrm{kg} / \mathrm{d})=\mathrm{Cr} \text { intake }(\mathrm{g} / \mathrm{d}) / \\
& \text { fecal } \mathrm{Cr}(\mathrm{g} / \mathrm{kg} \text { of } \mathrm{DM}) \text {. }
\end{aligned}
$$

Both BW and BCS changes were calculated by subtracting mean values obtained on wk $4,8,12$, or 16 from those recorded on $\mathrm{d}-3$ to 0 relative to the beginning of the study. Daily urinary volume was estimated from urinary concentration of creatinine assuming a constant creatinine excretion rate of $0.212 \mathrm{mmol} / \mathrm{kg}$ of BW (Chizzotti et al., 2008). Urinary excretion of allantoin, uric acid, total purine derivatives $(\mathbf{P D}=$ allantoin plus uric acid), and total $\mathrm{N}$ were calculated by multiplying the urinary volume times the concentrations of these individual metabolites in urine.

\section{Statistical Analyses}

Data were analyzed according to a randomized complete block design with repeated measures over time using the MIXED procedure of SAS (version 9.4, SAS Institute Inc., Cary, NC). Yields of milk and concentrations and yields of milk components, milk FA profile, serum concentrations of BUN, FA, and cortisol, urinary excretion of creatinine, uric acid, allantoin, total $\mathrm{PD}$, and total $\mathrm{N}$, ruminal concentrations of $\mathrm{NH}_{3}-\mathrm{N}$ and total VFA, and ruminal molar proportions of individual VFA were used as covariate variables in the statistical model reported below:

$$
\mathrm{Y}_{\mathrm{ijkl}}=\mu+\mathrm{B}_{\mathrm{i}}+\mathrm{T}_{\mathrm{j}}+\mathrm{W}_{\mathrm{k}}+\beta \mathrm{C}_{\mathrm{ijkl}}+\mathrm{T} \times \mathrm{W}_{\mathrm{jk}}+\varepsilon_{\mathrm{ijkl}},
$$

where $Y_{i j k l}=$ the dependent variable, $\mu=$ the overall mean, $B_{i}=$ the fixed effect of the ith block (pair of cows), $T_{j}=$ fixed effect of the jth treatment, $W_{k}=$ the fixed effect of the kth sampling week, $\beta=$ the regression coefficient of the covariate $\mathrm{C}, \mathrm{C}_{\mathrm{ijkl}}=$ the covariate variable for the lth cow within the ith block of the jth treatment in the kth week, $\mathrm{T} \times \mathrm{W}_{\mathrm{jk}}=$ the interaction between the jth treatment and the kth week, and $\varepsilon_{\mathrm{ijkl}}$ $=$ the error term. Intake and apparent total-tract digestibility of nutrients were analyzed without covariate adjustment. The SAS command REPEATED was used to model distinct residual variances, and among the covariance structures tested [i.e., spatial power, compound symmetry, autoregressive (1), and heterogeneous autoregressive (1)], the one with the least Bayesian information criterion was retained in the final model. The 
subject of the repeated measures was defined as cow nested within treatment and was treated as a random effect in the model. All reported values are LSM, with the PDIFF procedure of SAS (version 9.4) used to separate treatment means (CTRL vs. FLX). The Tukey's multiple comparison test was used to adjust LSM for week and treatment $\times$ week interactions. One cow assigned to the FLX diet died after completing the first sampling week (i.e., wk 4). She was replaced by another multiparous cow of similar BW, DIM, number of lactation, and milk yield in the beginning of wk 5 . However, statistical analyses for the second sampling week (i.e., wk 8) were conducted with missing values because data collected from wk 5 to 8 were used as covariate for the replacement cow. Significance was declared at $P \leq 0.05$ and trends at $0.05<P \leq 0.10$. The interaction term was removed from the model when $P>0.25$.

\section{RESULTS AND DISCUSSION}

\section{Herbage Mass and Feed Nutritional Composition}

Environmental conditions, herbage mass yield, allowance, and nutritional profile, and sward botanical composition are presented in Table 1. The nutritional composition of baleage, concentrate feeds, and pTMR is presented in Table 2. Mineral composition and profile of minor FA of herbage, baleage, and concentrate feeds are presented in Supplemental Tables S1 and S2 (https: //doi.org/10.3168/jds.2018-15376). Pregrazing herbage mass yield averaged $1,762 \mathrm{~kg}$ of $\mathrm{DM} /$ ha (range from 1,374 to $2,159 \mathrm{~kg}$ of DM/ha; Table 1) and was $663 \mathrm{~kg}$ of $\mathrm{DM} /$ ha lower than the mean value of $2,425 \mathrm{~kg}$ of DM/ ha (range from 1,824 to $2,806 \mathrm{~kg}$ of DM/ha) observed in our previous study (Brito et al., 2017). Year-to-year variation in environmental temperature and precipitation events are known to affect forage growth, which may explain these differences in herbage mass yield within the same site. Daily herbage allowance averaged $17.8 \mathrm{~kg}$ of DM/cow (range from 10.5 to $28.4 \mathrm{~kg}$ of DM/ cow; Table 1) and was $218 \%$ greater than estimated herbage DMI $($ mean $=5.59 \mathrm{~kg} / \mathrm{d})$. Thus, it appears that the amount of herbage offered to the cows did not restrict herbage consumption in the current study. In addition, postgrazing herbage mass averaged $1,361 \mathrm{~kg}$ of $\mathrm{DM} /$ ha showing that sufficient residual forage was left relative to pregrazing mass (Table 1).

The proportion of grasses in sampled herbage was numerically greatest in wk $4(67.3 \%)$, but relatively similar in wk 8, 12, and 16 (mean $=57.8 \%$; Table 1$)$. In contrast, the proportion of legumes $(10.5 \%)$ and weeds $(4.6 \%)$ was numerically lowest in wk 4 and increased thereafter $($ mean $=18.4$ and $9.3 \%$, respectively; Table
1). Brito et al. (2017) observed a similar botanical composition pattern in herbage samples collected throughout the grazing season. In these 2 studies, the mean proportion of grasses $(51 \%)$ was 2.8-fold greater than the mean proportion of legumes (18\%), which agrees with our previous work conducted in commercial dairies under organic certification (Dillard et al., 2016; Hafla et al., 2016). Herbage CP concentration followed the proportion of legumes and fluctuated across the grazing season, with numerically lowest values in wk 4 and 12 and greatest in wk 8 and 16 (Table 1). Concentrations of both NDF and ADF were numerically greatest in wk 4 and declined in subsequent weeks possibly because of changes in herbage botanical composition (i.e., decreased grasses and increased legumes and weeds over time), suggesting greater fiber concentration in grasses than legumes and weeds. Overall, the nutritive value of herbage offered herein (Table 1), including the concentration of macro- and microminerals (Supplemental Table S1; https://doi.org/10.3168/jds.2018-15376), was within values reported for herbage samples in the northeastern United States (Hafla et al., 2016; Brito et al., 2017).

$\alpha$-Linolenic acid was the FA with the greatest numerically proportion $($ mean $=47 \mathrm{~g} / 100 \mathrm{~g}$ of total FA; Table 1) in herbage samples, which agrees with our previous work (Brito et al., 2017; Hafla et al., 2018). Herbage cis-9, cis-12 18:2 (mean $=15.5 \mathrm{~g} / 100 \mathrm{~g}$ of total FA $)$ and 16:0 $($ mean $=15.2 \mathrm{~g} / 100 \mathrm{~g}$ of total FA $)$ were the second and third most abundant FA after ALA, respectively (Table 1). Some of the variation in the proportion of herbage FA with the advance of the grazing season may be explained by changes in plant species composition, plant growth stage, and seasonality (Boufaïed et al., 2003; Mir et al., 2006). As expected, ALA was the most predominant FA found in GFLX (42 g/100 g of total FA; Table 2), which is consistent with Resende et al. (2015) and Hafla et al. (2018) who reported ALA values of 53.9 and $51.6 \mathrm{~g} / 100$ of total FA, respectively. There were discrepancies between the ether extract and total FA concentrations of the pTMR, GFLX, and GRCSBM mix, with greater values observed for total FA than ether extract, which was unexpected (Table 2). Differences in extraction procedures, analytical method (gravimetric vs. chromatographic), and laboratory errors may have caused these discrepant results.

Diets were formulated to be isonitrogenous by balancing the GRC-SBM mix to the same CP concentration of GFLX. However, CP in GFLX (Table 2) was 5.3 percentage units greater than expected based on values reported by Resende et al. (2015), which resulted in different dietary concentrations of CP. Concentration of $\mathrm{NE}_{\mathrm{L}}$, estimated using the NRC (2001), was numerically 
greater in the FLX (1.63 Mcal $/ \mathrm{kg}$ of DM) than CTRL diet $(1.58 \mathrm{Mcal} / \mathrm{kg}$ of $\mathrm{DM})$ due to increased energy density provided by GFLX (data not shown).

\section{Animal Production and Serum Metabolites}

Most variables analyzed in this study resulted in significant week effects. These data are reported in Supplemental Tables S3 to S7 (https://doi.org/10.3168/jds .2018-15376) and are not discussed herein.

Treatment effects on DMI, yields of milk and milk components, feed efficiency, serum metabolites, BW, and BCS are presented in Table 3. Estimated herbage DMI and total DMI did not differ significantly between treatments and averaged 5.6 and $16.5 \mathrm{~kg} / \mathrm{d}$, respectively; a trend $(P=0.07)$ for a treatment $\times$ week interaction was observed for total supplement DMI. Herbage DMI averaged $34 \%$ of the total DMI and was 6 percentage units below the formulated target of $40 \%$ in the diet DM. Limitations associated with $\mathrm{Cr}_{2} \mathrm{O}_{3}$ (e.g., cyclic changes in fecal $\mathrm{Cr}$ concentration) and iADF (e.g., uncertainties about whether fecal iADF is chemically identical to herbage iADF) for estimating herbage DMI (Mayes and Dove, 2000) may have contributed to the deviation between formulated and actual proportion of herbage in the diet.

Yields of milk (mean $=18 \mathrm{~kg} / \mathrm{d}), 4 \% \mathrm{FCM}$ (mean $=19 \mathrm{~kg} / \mathrm{d}$ ), and ECM $($ mean $=20.6 \mathrm{~kg} / \mathrm{d}$ ) were not changed comparing CTRL versus the FLX diet (Table 3). Similarly, feed efficiency did not differ and averaged 1.11 (milk yield/total DMI), 1.17 (4\% FCM yield/total DMI), and 1.27 (ECM yield/total DMI) between treatments. We are not aware of any published study that used GFLX as a supplemental energy source during the grazing season, but research has been done supplementing flaxseed oil (Flowers et al., 2008; Rego et al., 2009) or a 70:30 weight basis blend of extruded flaxseed and wheat (Lerch et al., 2012a,b,c) to grazing dairy cows. Resende et al. (2015) observed linear decreases in DMI and yields of milk, 4\% FCM, and ECM in Jersey cows fed baleage supplemented with incremental amounts of $\operatorname{GFLX}(0,5,10$, or $15 \%$ of the diet DM). In contrast,

Table 1. Environmental conditions, herbage biomass, allowance, and nutritional profile, and sward botanical composition throughout the grazing season

Sampling collection week ${ }^{1}$

\begin{tabular}{|c|c|c|c|c|}
\hline \multirow[b]{2}{*}{ Item } & \multirow{2}{*}{ Wk 4} & & & \\
\hline & & Wk 8 & Wk 12 & Wk 16 \\
\hline Average relative humidity, ${ }^{3} \%$ & $83.6(53.6-98.2)$ & $81.3(40.9-100)$ & $78.7(29.0-97.5)$ & $76.6(44.4-100)$ \\
\hline Pregrazing herbage mass, $\mathrm{kg}$ of $\mathrm{DM} / \mathrm{ha}$ & 2,159 & 1,374 & 2,072 & 1,441 \\
\hline Pasture area, $\mathrm{m}^{2} /$ cow per $\mathrm{d}$ & 70.0 & 77.0 & 137 & 121 \\
\hline Daily herbage allowance, ${ }^{4} \mathrm{~kg}$ of DM/cow & 15.0 & 10.5 & 28.4 & 17.4 \\
\hline \multicolumn{5}{|c|}{ Sward botanical composition, ${ }^{5} \%$ of herbage DM } \\
\hline Dead materials & 17.6 & 9.20 & 20.0 & 14.3 \\
\hline \multicolumn{5}{|c|}{$\begin{array}{l}\text { Dead materlals } \\
\text { Nutritional composition, \% of DM unless noted }\end{array}$} \\
\hline $\mathrm{DM}, \%$ of fresh matter & 19.1 & 17.9 & 26.5 & 21.9 \\
\hline $\mathrm{CP}$ & 17.7 & 21.3 & 18.0 & 22.7 \\
\hline NDF & 59.3 & 46.7 & 48.8 & 45.4 \\
\hline $\mathrm{ADF}$ & 35.8 & 28.9 & 29.7 & 26.3 \\
\hline $16: 0$ & 14.9 & 16.0 & 15.4 & 14.5 \\
\hline $18: 0$ & 1.49 & 1.79 & 1.83 & 1.68 \\
\hline cis-9 18:1 & 2.40 & 2.08 & 2.49 & 2.05 \\
\hline cis-9, cis-12 18:2 & 16.6 & 15.5 & 15.6 & 14.3 \\
\hline cis- 9, cis- 12, cis- $15 \quad 18: 3$ & 46.5 & 45.5 & 44.6 & 49.9 \\
\hline
\end{tabular}

${ }^{1}$ Wk 4 (June 29 to July 5); wk 8 (July 27 to August 2); wk 12 (August 24 to 30); wk 16 (September 21 to 27).

${ }^{2}$ Values between parentheses indicate minimum and maximum air temperatures $\left({ }^{\circ} \mathrm{C}\right)$, respectively.

${ }^{3}$ Values between parentheses indicate minimum and maximum air relative humidity (\%), respectively.

${ }^{4}$ Daily herbage allowance $=\left[\right.$ pregrazing herbage mass $(\mathrm{kg}$ of DM/ha $) \times$ pasture area $\left(\mathrm{m}^{2} /\right.$ cow per day $\left.)\right] / 10,000$.

${ }^{5}$ Predominant herbage species found in the paddocks were orchardgrass (Dactylis glomerata L.), white clover (Trifolium repens L.), smooth bromegrass (Bromus inermis Leyss.), perennial ryegrass (Lolium perenne L.), and tall fescue (Festuca arundinacea Schreb.).

${ }^{6} \mathrm{NFC}=100-(\mathrm{CP}+\mathrm{NDF}+$ ether extract + ash $)$. 
GROUND FLAXSEED SUPPLEMENTATION FOR GRAZING DAIRY COWS

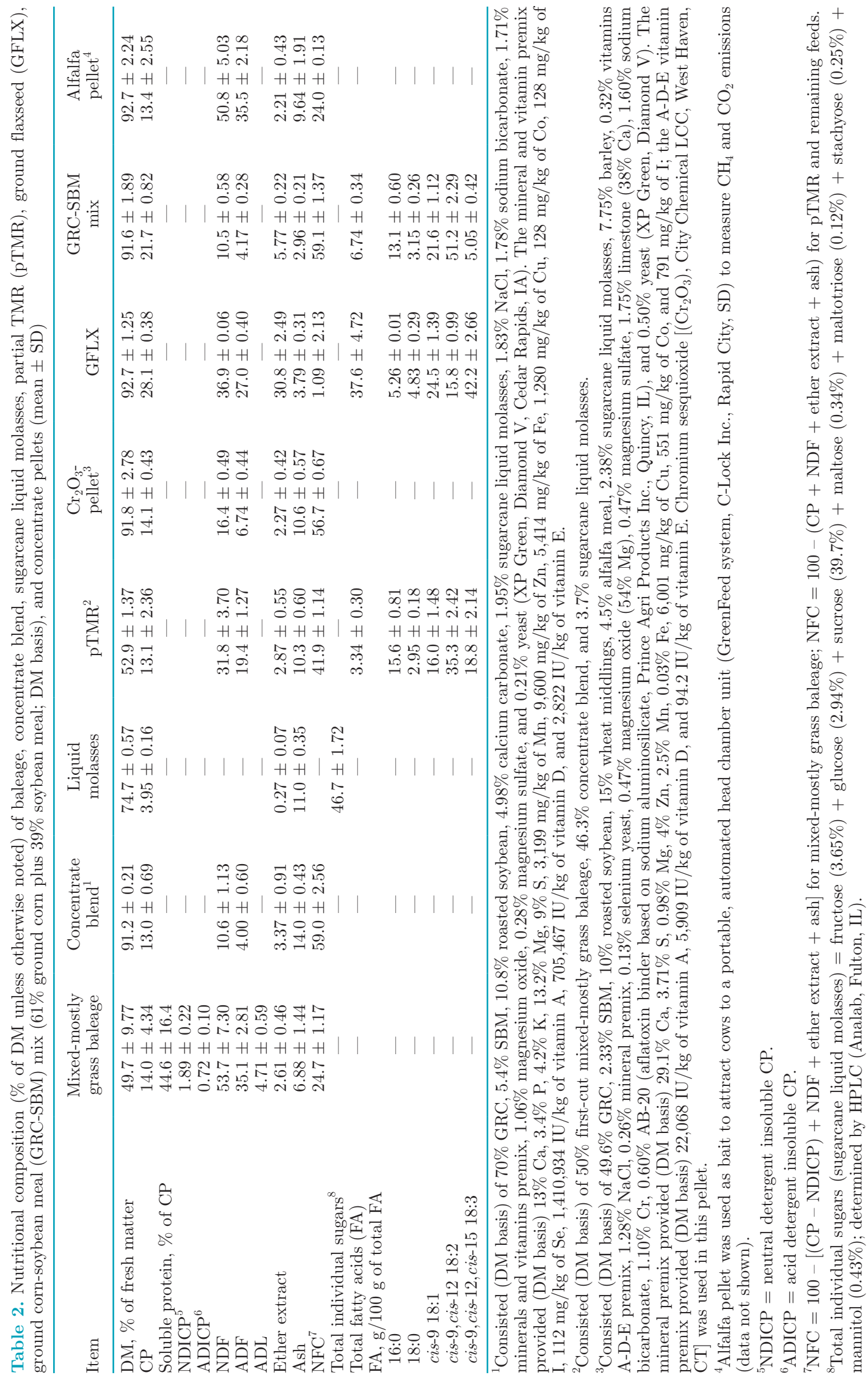


Ward et al. (2002) reported no changes in DMI and milk yield in dairy cows fed an alfalfa silage-based TMR supplemented with $8.3 \%$ of the diet DM as ground solin (i.e., linola, a flaxseed cultivar high in cis-9, cis-12 18:2), flaxseed, or canola. When dairy cows received hay and fodder beet supplemented with lower amounts of GFLX (4.4 or $6.6 \%$ of the diet DM), milk yield also did not change compared with the control ration (Collomb et al., 2004). Petit and Côrtes (2010) reported similar milk yield, but decreased DMI with feeding a

Table 3. Least squares means for DMI, milk yield and composition, feed efficiency, serum concentrations of blood metabolites, BW, and BCS in Jersey cows grazing cool-season perennial herbage supplemented with a partial TMR (pTMR) plus $10 \%$ of the diet DM as ground corn-soybean meal mix (control diet $=$ CTRL) or ground flaxseed (flaxseed diet $=$ FLX)

\begin{tabular}{|c|c|c|c|c|c|c|}
\hline \multirow[b]{2}{*}{ Item } & \multicolumn{2}{|c|}{ Treatment (TRT) } & \multirow[b]{2}{*}{ SEM } & \multicolumn{3}{|c|}{$P$-value ${ }^{1}$} \\
\hline & CTRL & FLX & & TRT & Week $(W)^{2}$ & $\mathrm{TRT} \times \mathrm{W}$ \\
\hline Estimated herbage DMI, ${ }^{3} \mathrm{~kg} / \mathrm{d}$ & 5.08 & 6.09 & 0.52 & 0.19 & $<0.01$ & 0.90 \\
\hline Supplemental grain DMI, ${ }^{4} \mathrm{~kg} / \mathrm{d}$ & 1.84 & 1.73 & - & - & - & - \\
\hline pTMR DMI, kg/d & 8.18 & 7.93 & 0.12 & 0.14 & $<0.001$ & 0.14 \\
\hline $\mathrm{Cr}_{2} \mathrm{O}_{3}$-containing pellet $\mathrm{DMI},{ }^{5} \mathrm{~kg} / \mathrm{d}$ & 0.84 & 0.84 & - & - & - & - \\
\hline Alfalfa pellet DMI ${ }^{6} \mathrm{~kg} / \mathrm{d}$ & 0.34 & 0.36 & 0.03 & 0.67 & $<0.001$ & 0.51 \\
\hline Total supplement DMI, ${ }^{7} \mathrm{~kg} / \mathrm{d}$ & 11.1 & 10.7 & 0.15 & 0.11 & $<0.001$ & 0.07 \\
\hline Total DMI, kg/d & 16.2 & 16.8 & 0.51 & 0.39 & $<0.001$ & 0.84 \\
\hline Total NFC intake, ${ }^{8} \mathrm{~kg} / \mathrm{d}$ & 6.02 & 5.03 & 0.10 & $<0.001$ & $<0.001$ & 0.89 \\
\hline Total fatty acid intake, ${ }^{9} \mathrm{~g} / \mathrm{d}$ & 563 & 1,076 & 21.3 & $<0.001$ & $<0.001$ & 0.89 \\
\hline Milk yield, $\mathrm{kg} / \mathrm{d}$ & 18.2 & 17.7 & 0.78 & 0.65 & $<0.001$ & 0.90 \\
\hline $4 \%$ FCM yield,${ }^{10} \mathrm{~kg} / \mathrm{d}$ & 19.6 & 18.3 & 0.78 & 0.27 & 0.08 & 0.79 \\
\hline ECM yield,${ }^{11} \mathrm{~kg} / \mathrm{d}$ & 21.2 & 19.9 & 0.80 & 0.27 & 0.28 & 0.81 \\
\hline Milk yield/total DMI, $\mathrm{kg} / \mathrm{kg}$ & 1.14 & 1.08 & 0.04 & 0.27 & $<0.001$ & 0.75 \\
\hline $4 \%$ FCM yield/total DMI, $\mathrm{kg} / \mathrm{kg}$ & 1.19 & 1.14 & 0.04 & 0.38 & $<0.001$ & 0.73 \\
\hline ECM yield/total DMI, $\mathrm{kg} / \mathrm{kg}$ & 1.29 & 1.24 & 0.04 & 0.42 & $<0.001$ & 0.78 \\
\hline Milk fat, $\%$ & 4.23 & 4.22 & 0.16 & 0.96 & 0.54 & 0.83 \\
\hline Milk fat, $\mathrm{kg} / \mathrm{d}$ & 0.80 & 0.74 & 0.03 & 0.26 & 0.12 & 0.71 \\
\hline Milk true protein, $\%$ & 3.44 & 3.48 & 0.05 & 0.56 & $<0.001$ & 0.94 \\
\hline Milk true protein, $\mathrm{kg} / \mathrm{d}$ & 0.65 & 0.61 & 0.02 & 0.17 & $<0.01$ & 0.94 \\
\hline Milk lactose, \% & 4.76 & 4.78 & 0.02 & 0.51 & $<0.01$ & 0.21 \\
\hline Milk lactose, $\mathrm{kg} / \mathrm{d}$ & 0.91 & 0.85 & 0.03 & 0.19 & 0.05 & 0.97 \\
\hline Milk SNF, \% & 9.12 & 9.22 & 0.06 & 0.23 & $<0.001$ & 0.95 \\
\hline Milk SNF, $\mathrm{kg} / \mathrm{d}$ & 1.72 & 1.65 & 0.07 & 0.48 & 0.90 & 0.99 \\
\hline Milk TS, \% & 13.5 & 13.3 & 0.19 & 0.67 & $<0.001$ & 0.85 \\
\hline Milk TS, kg/d & 2.52 & 2.38 & 0.10 & 0.33 & 0.47 & 0.90 \\
\hline MUN, mg/dL & 14.5 & 13.4 & 0.35 & 0.05 & $<0.001$ & $<0.01$ \\
\hline Milk SCC, $\times 1,000$ cells & 148 & 135 & 119 & 0.92 & 0.19 & 0.96 \\
\hline Milk $\mathrm{N}$ yield, $\%$ of $\mathrm{N}$ intake & 24.1 & 22.4 & 0.76 & 0.13 & $<0.001$ & 0.78 \\
\hline BUN, mg/dL & 12.8 & 14.0 & 0.30 & 0.02 & $<0.001$ & 0.03 \\
\hline Serum fatty acids, $\mathrm{mg} / \mathrm{mL}$ & 210 & 209 & 12.5 & 0.93 & $<0.001$ & 0.12 \\
\hline Serum cortisol, $\mathrm{ng} / \mathrm{mL}$ & 63.4 & 59.5 & 5.70 & 0.64 & 0.35 & 0.25 \\
\hline $\mathrm{BW}, \mathrm{kg}$ & 430 & 430 & 2.62 & 0.84 & $<0.001$ & 0.54 \\
\hline BW change, $\mathrm{kg} / \mathrm{d}$ & 0.63 & 0.60 & 0.09 & 0.84 & $<0.001$ & 0.54 \\
\hline $\mathrm{BCS}^{12}$ & 2.94 & 3.03 & 0.05 & 0.26 & $<0.01$ & 0.13 \\
\hline BCS change, point $/ 28 \mathrm{~d}$ & 0.13 & -0.03 & 0.07 & 0.13 & $<0.01$ & 0.13 \\
\hline
\end{tabular}

${ }^{1}$ Significance was declared at $P \leq 0.05$ and trends at $0.05<P \leq 0.10$.

${ }^{2}$ Wk 4 (June 29 to July 5); wk 8 (July 27 to August 2); wk 12 (August 24 to 30); wk 16 (September 21 to 27 ).

${ }^{3}$ Estimated herbage DMI, $\mathrm{kg} / \mathrm{d}=\{[$ fecal output $(\mathrm{kg} / \mathrm{d}) \times$ fecal indigestible ADF $(\mathrm{g} / \mathrm{kg}$ of DM) - total supplement indigestible ADF $(\mathrm{g} / \mathrm{d})\} /$ herbage indigestible ADF (g/kg of DM) (Hellwing et al., 2015).

${ }^{4}$ A fixed amount of a ground corn-soybean meal mix (61\% ground corn plus $39 \%$ soybean meal; DM basis) or ground flaxseed was fed during the study. Complete consumption of these supplemental sources, which were top-dressed to the pTMR, was assumed.

${ }^{5} \mathrm{~A}$ fixed amount of $\mathrm{Cr}_{2} \mathrm{O}_{3}$ pellet was fed during the study; cows completely consumed the $\mathrm{Cr}_{2} \mathrm{O}_{3}$ pellet, which was confirmed visually.

${ }^{6}$ Alfalfa pellet was used as bait to attract cows to a portable, automated head chamber unit (GreenFeed system, C-Lock Inc., Rapid City, SD) to measure $\mathrm{CH}_{4}$ and $\mathrm{CO}_{2}$ emissions (data not shown).

${ }^{7}$ Total supplement DMI $(\mathrm{kg} / \mathrm{d})=$ pTMR DMI $(\mathrm{kg} / \mathrm{d})+$ ground corn-soybean meal mix DMI or ground flaxseed DMI $(\mathrm{kg} / \mathrm{d})+$ Cr $\mathrm{O}_{3}$ pellet DMI $(\mathrm{kg} / \mathrm{d})+$ alfalfa pellet DMI $(\mathrm{kg} / \mathrm{d})$.

${ }^{8} \mathrm{NFC}=100-(\mathrm{CP}+\mathrm{NDF}+$ ether extract + ash $)$.

${ }^{9}$ This excludes $\mathrm{Cr}_{2} \mathrm{O}_{3}$ pellet and alfalfa pellet intake because these pellets were not analyzed for fatty acids.

${ }^{10} 4 \%$ FCM yield $=[0.40 \times$ milk yield $(\mathrm{kg} / \mathrm{d})]+[15 \times$ milk fat yield $(\mathrm{kg} / \mathrm{d})]$ (Gaines and Davidson, 1923)

${ }^{11} \mathrm{ECM}$ yield $=[0.327 \times$ milk yield $(\mathrm{kg} / \mathrm{d})]+[12.95 \times$ milk fat yield $(\mathrm{kg} / \mathrm{d})]+[7.2 \times$ milk true protein yield $(\mathrm{kg} / \mathrm{d})]($ Orth, 1992$)$.

${ }^{12} \mathrm{On}$ a 1 to 5 scale in quarter-point increments where $1=$ thin and $5=$ fat. 
corn silage-haylage-based TMR supplemented $(7.2 \%$ of the diet DM) or not with GFLX. Recently, we reported that $6 \%$ GFLX fed to dairy cows offered high-forage diets did not affect milk yield during a study conducted over 2 winter seasons in 9 commercial organic dairies in the northeastern United States (Hafla et al., 2018). Altogether, these results show inconsistent responses in DMI and milk yield in lactating dairy cows fed varying amounts of GFLX.

Concentrations and yields of milk components, as well as milk SCC were not changed between treatments (Table 3). Resende et al. (2015) observed linear decreases in the yields of milk fat and true protein, and milk true protein concentration when feeding incremental amounts of GFLX, with the lowest values observed for the diet containing the greatest level of GFLX (i.e., $15 \%)$. On the contrary, previous researchers reported no changes in the concentrations and yields of milk fat and true protein in rations containing GFLX supplemented at 4.4 to $7.2 \%$ of the diet DM (Collomb et al., 2004; Petit and Côrtes, 2010; Hafla et al., 2018). Ward et al. (2002) observed no changes in the concentration and yield of milk fat in dairy cows offered (DM basis) $8.3 \%$ GFLX compared with the control diet, but concentration and yield of milk protein decreased significantly. It is well documented that excess dietary fat $(>5 \%$ ether extract) has detrimental effects on ruminal microbial activity and metabolic processes, ultimately depressing milk yield and synthesis of milk fat and protein in the mammary gland (Dhiman et al., 2000; Bauman and Griinari, 2001; NRC, 2001). However, yields of milk and milk components were not changed in the current study despite dietary ether extract concentration exceeding the 5-percentage threshold with GFLX (i.e., $6.1 \%)$. This suggests that ingredient and nutritional composition of the basal diet, level of DMI and milk yield, and stage of lactation are among factors that may interact with each other to modulate intake and synthesis of milk and milk components, thus resulting in discrepant results across the literature. Aikman et al. (2008) observed differences in feeding behavior, apparent total-tract NDF digestibility, and rate of digesta passage between Holstein and Jersey cows, suggesting that some of the inconsistent results reported in the literature for DMI, milk yield, and milk composition in response to feeding varying amounts of GFLX may be explained by a breed effect.

Concentration of MUN was lower in wk $8(P<0.001)$ and $16(P=0.05)$, whereas that of BUN was greater in wk $4(P=0.01), 8(P<0.01)$, and $12(P<0.01)$ in cows offered FLX versus the CTRL diet (Table 4 ). These contradictory responses between MUN and BUN, as well as their respective treatment by week interac- tions, are difficult to reconcile. It is well established that the concentration of BUN directly affects that of MUN because urea freely diffuses from blood to milk (Oltner and Wiktorsson, 1983; Roseler et al., 1993; Gustafsson and Palmquist, 1993). However, plasma urea $\mathrm{N}$ rises and falls throughout the day, reflecting the dynamic nature of $\mathrm{N}$ metabolism (Gustafsson and Palmquist, 1993). In the current study, BUN was determined in composited serum samples taken 2 times daily ( $\sim 515$ and $1500 \mathrm{~h}$ ), whereas MUN was derived from composited milk samples collected over 4 consecutive milkings. This sampling schedule captured part of the diurnal feeding cycle for BUN and the whole feeding cycle for MUN, which may have played a role in their discrepant results. Although total $\mathrm{N}$ intake from the supplement containing GFLX increased in wk $8[+16$ $\mathrm{g} / \mathrm{d}$; treatment $\times$ week interaction $(P=0.04)$; data not shown], herbage $\mathrm{N}$ intake did not differ between treatments (data not shown), suggesting that MUN and BUN interactions were not entirely associated with supplement or herbage $\mathrm{N}$ intake.

Milk-N efficiency (mean $=23.3 \%$ ), as well as serum concentrations of FA (mean $=210 \mathrm{mEq} / \mathrm{L})$ and cortisol $($ mean $=61.5 \mathrm{ng} / \mathrm{mL}), \mathrm{BW}($ mean $=435 \mathrm{~kg})$, BW change $($ mean $=0.62 \mathrm{~kg} / \mathrm{d})$, BCS $($ mean $=2.99)$, and $\mathrm{BCS}$ change $($ mean $=0.05$ point $/ 28 \mathrm{~d}$ ) were similar between treatments (Table 3). Likewise, Resende et al. (2015) observed no effects of varying amounts of GFLX supplementation on plasma FA (mean $=221 \mathrm{mEq} / \mathrm{L})$, serum cortisol $($ mean $=81.9 \mathrm{ng} / \mathrm{mL})$, and $\mathrm{BW}$ change (mean $=-0.20 \mathrm{~kg} / \mathrm{d})$. Mean serum cortisol concentration was $33 \%$ lower herein that in our experiment conducted in the winter season (Resende et al., 2105). This suggests that cows may have been susceptible to less stressful conditions during the summer than winter.

\section{Milk FA Profile}

Treatment effects on milk proportions of SFA are presented in Table 5. Out of 15 individual SFA that were significantly changed by treatments, 3 increased (i.e., 18:0, 20:0, 24:0) and 12 decreased in cows offered the FLX diet. The $\Sigma$ odd-chain FA, $\Sigma<16 \mathrm{C}$ FA, and $\Sigma 16 \mathrm{C}$ FA decreased $(P \leq 0.02)$, whereas $\Sigma 18 \mathrm{C}$ FA increased $(P<0.001)$ in FLX versus the CTRL diet. In addition, compared with the CTRL diet, feeding FLX decreased milk yield of $\Sigma<16 \mathrm{C} \mathrm{FA} \mathrm{(213} \mathrm{vs.} 158 \mathrm{~g} / \mathrm{d}$, respectively; $P<0.01$; data not shown) and increased that of $\Sigma 18 \mathrm{C} \mathrm{FA}$ (272 vs. $332 \mathrm{~g} / \mathrm{d}$, respectively; $P=$ 0.03 ; data not shown), which is consistent with the inverse relationship between de novo synthesis of FA in the mammary gland and intake of PUFA (Chilliard et al., 2000). Similar responses were observed in dairy 


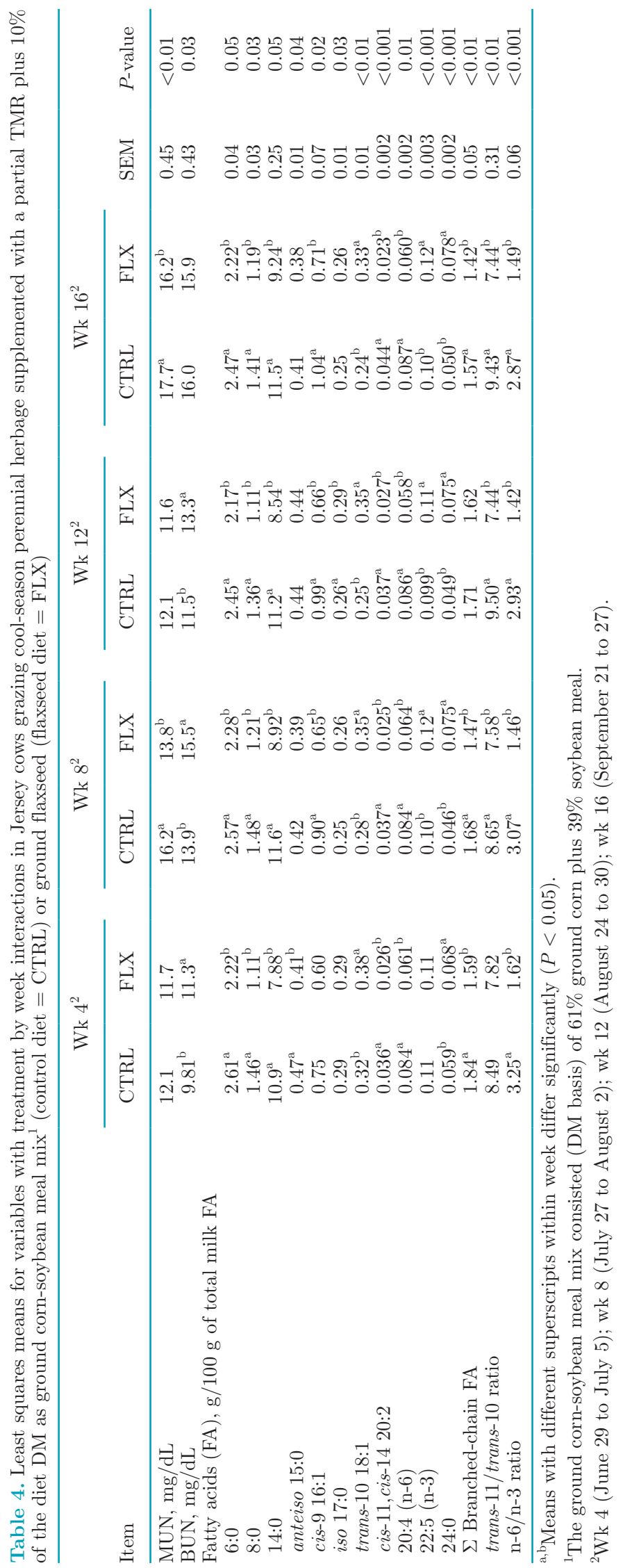


Table 5. Least squares means for milk proportions of individual SFA and sum of groups of fatty acids (FA) in Jersey cows grazing cool-season perennial herbage supplemented with a partial TMR plus $10 \%$ of the diet DM as ground corn-soybean meal mix ${ }^{1}$ (control diet $=$ CTRL) or ground flaxseed (flaxseed diet $=$ FLX)

\begin{tabular}{|c|c|c|c|c|c|c|}
\hline \multirow{2}{*}{$\begin{array}{l}\mathrm{FA}, \mathrm{g} / 100 \mathrm{~g} \text { of } \\
\text { total milk FA }\end{array}$} & \multicolumn{2}{|c|}{ Treatment (TRT) } & \multirow[b]{2}{*}{ SEM } & \multicolumn{3}{|c|}{$P$-value ${ }^{2}$} \\
\hline & CTRL & FLX & & TRT & Week $(W)^{3}$ & $\mathrm{TRT} \times \mathrm{W}$ \\
\hline $4: 0$ & 5.31 & 5.23 & 0.08 & 0.53 & $<0.001$ & 0.98 \\
\hline $6: 0$ & 2.52 & 2.22 & 0.03 & $<0.001$ & $<0.001$ & 0.05 \\
\hline $8: 0$ & 1.43 & 1.16 & 0.03 & $<0.001$ & $<0.001$ & 0.03 \\
\hline 10:0 & 3.09 & 2.28 & 0.09 & $<0.001$ & $<0.001$ & 0.06 \\
\hline 11:0 & 0.039 & 0.028 & 0.003 & 0.01 & $<0.001$ & 0.93 \\
\hline $12: 0$ & 3.48 & 2.45 & 0.10 & $<0.001$ & $<0.001$ & 0.21 \\
\hline $13: 0$ & 0.082 & 0.068 & 0.003 & $<0.01$ & $<0.001$ & 0.67 \\
\hline 14:0 & 11.3 & 8.64 & 0.21 & $<0.001$ & $<0.001$ & 0.05 \\
\hline iso $14: 0$ & 0.16 & 0.13 & 0.01 & $<0.01$ & $<0.001$ & 0.16 \\
\hline $15: 0$ & 0.91 & 0.80 & 0.01 & $<0.001$ & $<0.001$ & 0.09 \\
\hline iso 15:0 & 0.25 & 0.23 & 0.01 & 0.06 & $<0.001$ & 0.22 \\
\hline anteiso $15: 0$ & 0.44 & 0.41 & 0.01 & 0.12 & $<0.001$ & 0.04 \\
\hline $16: 0$ & 26.7 & 19.7 & 0.38 & $<0.001$ & $<0.001$ & 0.32 \\
\hline iso $16: 0$ & 0.29 & 0.22 & 0.01 & $<0.001$ & $<0.01$ & 0.13 \\
\hline $17: 0$ & 0.43 & 0.39 & 0.01 & $<0.01$ & $<0.001$ & 0.13 \\
\hline iso $17: 0$ & 0.26 & 0.27 & 0.01 & 0.15 & $<0.001$ & 0.03 \\
\hline anteiso 17:0 & 0.30 & 0.27 & 0.01 & 0.11 & $<0.001$ & 0.36 \\
\hline $18: 0$ & 12.0 & 16.7 & 0.22 & $<0.001$ & $<0.001$ & 0.10 \\
\hline $20: 0$ & 0.18 & 0.19 & 0.003 & 0.01 & $<0.001$ & 0.32 \\
\hline $22: 0$ & 0.071 & 0.066 & 0.002 & 0.08 & $<0.001$ & 0.72 \\
\hline $24: 0$ & 0.051 & 0.074 & 0.002 & $<0.001$ & 0.02 & $<0.001$ \\
\hline \multicolumn{7}{|l|}{ Sum of FA } \\
\hline$\Sigma$ Odd-chain ${ }^{4}$ & 1.59 & 1.38 & 0.02 & $<0.001$ & $<0.001$ & 0.09 \\
\hline$\Sigma$ Branched-chain ${ }^{5}$ & 1.70 & 1.52 & 0.04 & 0.02 & $<0.001$ & $<0.01$ \\
\hline$\Sigma<16 \mathrm{C}^{6}$ & 28.3 & 22.9 & 0.43 & $<0.001$ & $<0.001$ & 0.14 \\
\hline$\Sigma 16 \mathrm{C}^{7}$ & 27.6 & 20.4 & 0.39 & $<0.001$ & $<0.001$ & 0.30 \\
\hline$\Sigma 18 \mathrm{C}^{8}$ & 36.2 & 47.2 & 0.85 & $<0.001$ & $<0.001$ & 0.29 \\
\hline
\end{tabular}

${ }^{1}$ The ground corn-soybean meal mix consisted (DM basis) of $61 \%$ ground corn plus $39 \%$ soybean meal.

${ }^{2}$ Significance was declared at $P \leq 0.05$ and trends at $0.05<P \leq 0.10$.

${ }^{3}$ Wk 4 (June 29 to July 5); wk 8 (July 27 to August 2); wk 12 (August 24 to 30); wk 16 (September 21 to 27).

${ }^{4} \Sigma$ odd-chain FA $=11: 0+13: 0+15: 0+17: 0+$ cis-9 17:1 (this FA is reported in Table 6).

${ }^{5} \Sigma$ branched-chain $\mathrm{FA}=$ iso 14:0 + iso 15:0 + anteiso 15:0 + iso 16:0 + iso 17:0 + anteiso 17:0.

${ }^{6} \Sigma<16 \mathrm{C} \mathrm{FA}$ (originated from de novo synthesis in the mammary gland) $=4: 0+6: 0+8: 0+10: 0+10: 1$ (this FA is reported in Table 6) + 12:0 + 14:0 + cis-9 14:1 (this FA is reported in Table 6).

${ }^{7} \mathrm{\Sigma} 16 \mathrm{C}$ FA (originated from de novo synthesis in the mammary gland and extraction from plasma) $=16: 0+$ cis-9 16:1 (this FA is reported in Table 6).

${ }^{8} \Sigma 18 \mathrm{C}$ FA (originated from plasma extraction) $=18: 0+18 \mathrm{C}$ UFA (reported in Table 6 ).

cows fed GFLX under confinement management (Collomb et al., 2004; Petit and Côrtes, 2010; Resende et al., 2015) or incremental amounts of flaxseed oil (0, 170, 340, or $510 \mathrm{~g} / \mathrm{d}$ ) under grazing conditions (Flowers et al., 2008). Decreased $\Sigma$ odd- and branched-chain FA in milk fat of cows offered the FLX diet suggests less duodenal flow of microbial protein as these FA come mostly from ruminal microorganisms (Fievez et al., 2012), or that GFLX depressed growth of microbes that synthesize odd- and branched-chain FA in the rumen.

Treatment effects on milk proportions of UFA are presented in Table 6. Out of 19 individual UFA significantly changed by treatments, 10 increased and 9 decreased with feeding the FLX diet. Whereas $\Sigma \mathrm{n}-6$ FA decreased $(P<0.001), \Sigma n-3 \mathrm{FA}$, trans-18:1 FA, and cis-18:1 FA increased $(P \leq 0.01)$ in milk fat of cows offered FLX. Decreased $\Sigma$ n- 6 FA and increased $\Sigma$ n-3
FA are in line with the concentrations of cis-9,cis-12 18:2 (15.8 vs. $51.2 \mathrm{~g} / 100 \mathrm{~g}$ of FA) and ALA (5.05 vs. $42.2 \mathrm{~g} / 100 \mathrm{~g}$ of FA) in GRC-SBM mix and GFLX, respectively (Table 2). Likewise, elevated $\Sigma$ trans-18:1 FA and $\Sigma$ cis-18:1 FA reflects increased intake of ALA $(+146 \mathrm{~g} / \mathrm{d} ; P<0.001$; data not shown $)$ in cows offered FLX versus the CTRL diet. Similar responses have been reported in confined dairy cows fed TMR containing GFLX (Petit and Côrtes, 2010; Resende et al., 2015) or flaxseed oil (Brossillon et al., 2018), and in grazing dairy cows supplemented with increasing levels of flaxseed oil (Flowers et al., 2008).

Cows offered the FLX diet had lower proportion $(P$ $<0.001$ ) of cis-9, cis-12 18:2 in milk fat than those fed CTRL (Table 6) despite increased intake of cis-9, cis-12 18:2 (305 vs. $172 \mathrm{~g} / \mathrm{d}$, respectively; $P<0.001$; data not shown). A similar response was observed by Re- 
Table 6. Least squares means for milk proportions of individual UFA and sum of groups of fatty acids (FA) in Jersey cows grazing cool-season perennial herbage supplemented with a partial TMR plus $10 \%$ of the diet DM as ground corn-soybean meal mix ${ }^{1}($ control diet $=$ CTRL) or ground flaxseed (flaxseed diet $=$ FLX)

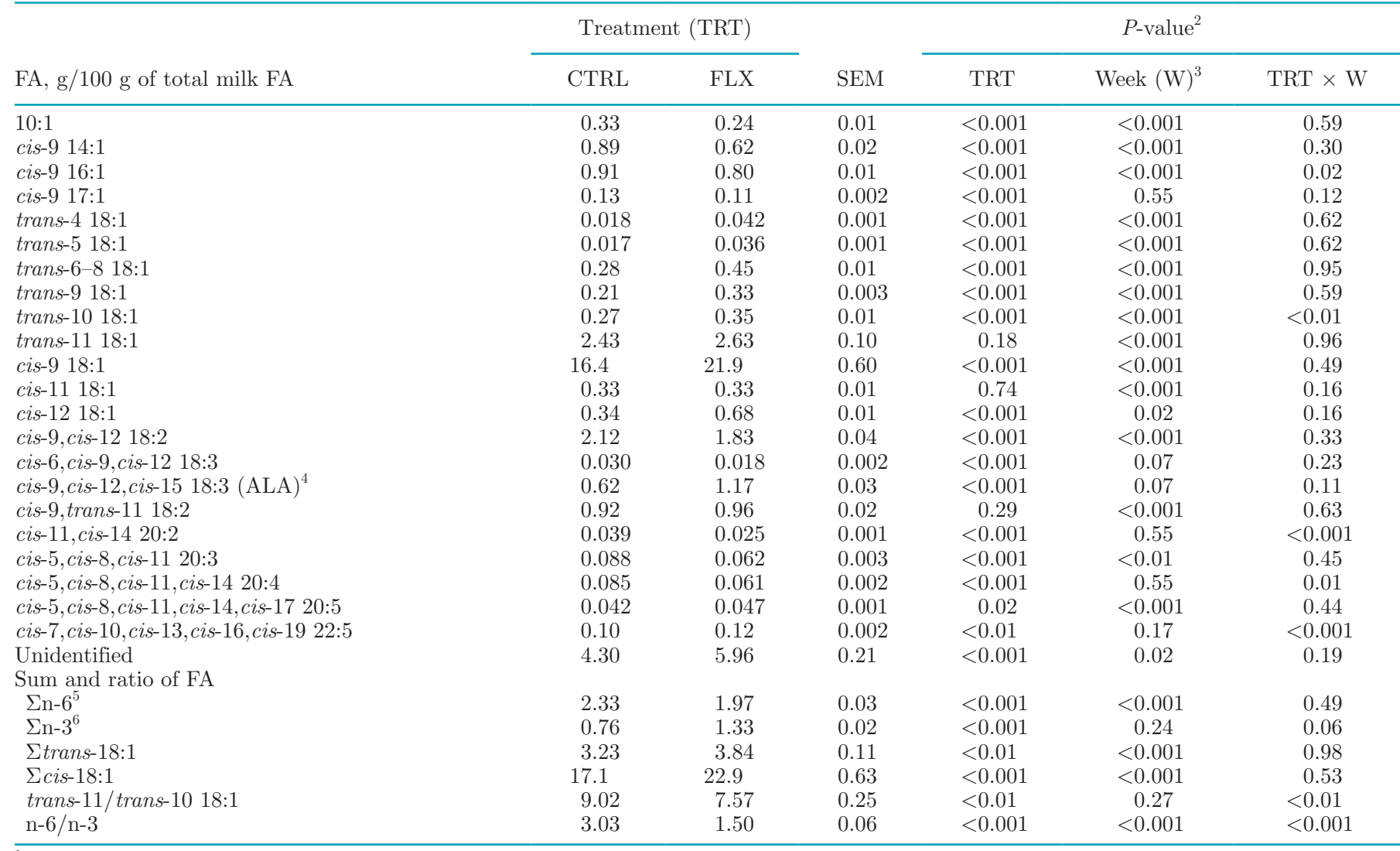

${ }^{1}$ The ground corn-soybean meal mix consisted (DM basis) of $61 \%$ ground corn plus $39 \%$ soybean meal.

${ }^{2}$ Significance was declared at $P \leq 0.05$ and trends at $0.05<P \leq 0.10$.

${ }^{3}$ Wk 4 (June 29 to July 5); wk 8 (July 27 to August 2); wk 12 (August 24 to 30); wk 16 (September 21 to 27).

${ }^{4} \mathrm{ALA}=\alpha$-linolenic acid.

${ }^{5} \mathrm{Nn}-6 \mathrm{FA}=$ cis-9,cis-12 18:2 + cis-8,cis-11,cis-14 20:3 + cis-5,cis-8,cis-11,cis-14 20:4.

${ }^{6} \mathrm{Nn}-3 \mathrm{FA}=$ cis-9,cis-12,cis-15 18:3 + cis-5,cis-8,cis-11,cis-14,cis-17 20:5 + cis-7,cis-10,cis-13,cis-16, cis-19 $22: 5$.

sende et al. (2015), thus suggesting extensive ruminal biohydrogenation of dietary cis-9,cis-12 18:2 as shown previously (Loor et al., 2004). The milk proportion of ALA increased $(P<0.001$; Table 6$)$ by $89 \%$ with feeding the FLX diet due to enhanced intake of ALA as discussed earlier. Positive effects of GFLX supplementation on milk ALA are well documented in the literature (Ward et al., 2002; Collomb et al., 2004; Petit and Côrtes, 2010; Resende et al., 2015). Milk proportions of both trans-11 18:1 and cis-9,trans-11 18:2 did not differ and averaged 2.53 and $0.94 \mathrm{~g} / 100 \mathrm{~g}$ of total FA, respectively (Table 6). We observed linear increases in trans-11 18:1 and cis-9,trans-11 18:2 when cows were fed grass-legume baleage supplemented with incremental amounts of GFLX (Resende et al., 2015). However, while 10\% GFLX elevated milk trans-11 $18: 1$ by $32 \%$ and cis- 9 ,trans- 11 18:2 by $27 \%$ compared with the control diet, $15 \%$ GFLX increased these 2 FA by 96 and
$85 \%$, respectively (Resende et al., 2015). No changes in trans-11 18:1 and cis-9,trans-11 18:2 were observed in cows fed corn silage-haylage-based diets supplemented with 7.2\% GFLX (Petit and Côrtes, 2010), or hay-, baleage-, or haylage-based diets supplemented with 6\% GFLX (Hafla et al., 2018). Collomb et al. (2004) observed significant increases in trans-11 18:1 and cis9,trans-11 18:2 in dairy cows receiving hay and fodder beet supplemented with 6.6\% GFLX, but these FA were not changed with feeding $4.4 \%$ GFLX. In contrast, when $8.3 \%$ GFLX (DM basis) was fed to dairy cows receiving an alfalfa silage-based TMR, both trans-11 18:1 and cis-9,trans-11 18:2 decreased compared with the control diet (Ward et al., 2002).

Discrepant responses in milk trans-11 18:1 and cis9,trans-11 18:2 have been also observed in grazing dairy cows supplemented with flaxseed oil (Flowers et al., 2008; Rego et al., 2009) or extruded flaxseed (Lerch et 
al., 2012b,c). For instance, flaxseed oil $(0.5 \mathrm{~kg} / \mathrm{d}$ per cow) increased trans-11 18:1 and cis-9,trans-11 18:2 in milk fat (Flowers et al., 2008; Rego et al., 2009), whereas trans-11 18:1 did not change and cis-9,trans-11 18:2 decreased in cows fed $4.5 \mathrm{~kg} / \mathrm{d}$ of a 70:30 weight basis blend of extruded flaxseed and wheat over 2 lactations (Lerch et al., 2012b,c). Lerch et al. (2012b,c) hypothesized that reduced dietary concentration of starch in cows fed the extruded flaxseed-based concentrate may have resulted in a more extensive ruminal reduction of trans-11 18:1 to 18:0, ultimately decreasing the proportion of cis-9,trans-11 18:2 in milk fat. In the current study, total intake of NFC was $20 \%$ lower in cows fed FLX versus the CTRL diet (Table 3), which may explain the lack of GFLX effect on milk trans-11 18:1 and cis-9,trans-11 18:2. Overall, these inconsistent results documented in the literature appear to be influenced by the amount of GFLX supplementation, forage type used in the basal diet, form of flaxseed used (ground, oil, or extruded), forage-to-concentrate ratio, dietary starch or NFC concentration, among other factors. Alternatively, White et al. (2001) reported greater milk proportion of cis-9,trans-11 18:2 in Holstein than Jersey cows, thus suggesting that breed may be also involved in the discrepant milk FA results among studies.

A consistent pattern was not observed regarding the treatment by week interactions observed for the proportions of milk FA presented in Table 4. Except for trans-10 18:1, cis-7,cis-10,cis-13, cis-16, cis-19 22:5, and 24:0, all remaining individual FA, $\Sigma$ branched-chain FA, trans-11/trans-10 ratio, and n- $6 / \mathrm{n}-3$ FA ratio were lower in cows offered FLX versus the CTRL diet during at least 1 out of the 4 sampling weeks. Decreased milk n-6/n-3 FA ratio with feeding FLX is consistent with increased intake of ALA (279 vs. $133 \mathrm{~g} / \mathrm{d}$, respectively; $P<0.001$; data not shown). Furthermore, potential detrimental effects of GFLX-oil on growth of ruminal microbes that synthesize branched-chain FA may have been associated with decreased proportion of these FA in milk fat.

\section{Intake and Apparent Total-Tract Digestibility of Nutrients}

Treatment effects on total intake and apparent totaltract digestibility of nutrients are presented in Table 7 . Total NDF $(+0.78 \mathrm{~kg} / \mathrm{d} ; P=0.04)$, ADF $(+0.58 \mathrm{~kg} / \mathrm{d}$; $P=0.02)$, and $\mathrm{CP}(+0.20 \mathrm{~kg} / \mathrm{d} ; P=0.10)$ intakes were greater in cows offered FLX than the CTRL diet. These results are consistent with numerically greater concentrations of NDF, ADF, and CP in GFLX compared with GRC-SBM mix (Table 2). Apparent total-tract digestibility of DM tended to decrease $(-1.5$ percent- age unit; $P=0.10)$, whereas digestibilities of OM $(-1.8$ percentage unit; $P=0.04)$ and NDF $(+4.2$ percentage units; $P<0.01)$ decreased or increased, respectively, with feeding FLX versus the CTRL diet (Table 7). Both $\mathrm{ADF}$ and $\mathrm{CP}$ digestibilities did not change and averaged 44.2 and $62.6 \%$, respectively. Our NDF digestibility is consistent with Gonthier et al. (2004) who reported an average 6.5-percentage unit increase in total-tract NDF digestibility when lactating dairy cows were fed a TMR in which raw, micronized, or extruded flaxseed (12.5 to $12.7 \%$ of the diet DM) replaced grass and corn silages, high-moisture corn, and SBM. Gonthier et al. (2004) proposed that the fibrous portion of flaxseed may be more digestible than that from the basal diet. It appears that hemicellulose was associated with the observed improvement in NDF digestibility in cows offered FLX in the current study due to the lack of treatments effects on ADF digestibility (Table 7). In fact, apparent total-tract digestibility of hemicellulose, which was determined by subtracting NDF from ADF digestibility, increased $(P=0.04)$ with feeding FLX $($ mean $=7.73 \%)$ versus the CTRL diet $(6.14 \%$; data not shown). Despite increased NDF and hemicellulose digestibilities, cows fed the FLX diet showed decreased OM digestibility suggesting that fiber from GFLX had less of an effect on diet OM digestion than starch from GRC-SBM mix.

Limited information is available regarding GFLX supplementation on nutrient digestibility in both in vivo and in vitro. Soder et al. (2012) observed linear reductions in DM, OM, and NDF digestibilities in continuous culture fermentors dosed with orchardgrass herbage and incremental amounts of GFLX $(0,5,10$, or $15 \%$ of the diet DM). In a subsequent study, DM, OM, and NDF digestibilities did not change when orchardgrass herbage was supplemented ( $10 \%$ of the diet DM) with GFLX, ground canola seed, or ground sunflower seed during continuous culture fermentation (Soder et al., 2013a). Resende et al. (2015) reported that apparent total-tract DM digestibility decreased linearly, whereas digestibilities of OM, NDF, and ADF tended to decrease linearly in Jersey cows fed increasing amounts of GFLX $(0,5,10$, or $15 \%$ of the diet DM). Scholljegerdes and Kronberg (2010) also observed decreased total-tract digestibility of OM, but that of NDF was not affected in beef heifers grazing summer native range herbage supplemented with a cracked corn-SBM mix ( $\sim 13 \%$ of the diet DM) or GFLX ( $\sim 9 \%$ of the diet DM). Overall, the effect of GFLX on nutrient digestibility appears to be dose-dependent, with levels $>10 \%$ of the diet DM exerting a stronger depression on nutrient digestibility than lower amounts due to the potential detrimental effect of excess dietary fat on ruminal metabolism. 


\section{Ruminal Fermentation Profile}

Treatment effects on ruminal fermentation profile are presented in Table 7 . Ruminal concentrations of $\mathrm{NH}_{3}-\mathrm{N}$ (mean $=12.1 \mathrm{mg} / \mathrm{dL}$ ) and total VFA (mean $=75.5 \mathrm{mM}$ ) did not differ in cows offered CTRL or the FLX diet. Similarly, ruminal molar proportions of acetate, propionate, isobutyrate, valerate, and isovalerate did not change between treatments; a trend $(P=$ 0.08 ) for reduced ruminal proportion of butyrate was observed with feeding the FLX diet. Ruminal acetateto-propionate ratio decreased $(P=0.05)$ in cows fed FLX versus the CTRL diet. However, neither ruminal acetate nor ruminal propionate changed in response to treatments, thus suggesting that the drop in the acetate-to-propionate ratio with feeding FLX was an artifact of the ratio calculation. The modest effect of GFLX supplementation on ruminal fermentation in the current study may be explained by the amount fed (i.e., $10 \%$ of the diet DM). When incremental amounts of GFLX were fed in vitro (Soder et al., 2012) or in vivo (Resende et al., 2015), there were linear changes in ruminal proportions of acetate, propionate, butyrate, and acetate-to-propionate ratio, with the lowest or greatest values observed for the diet with 15\% GFLX. In contrast, fewer changes were observed in ruminal fermentation profile when supplementing GFLX at $10 \%$ of the diet DM in 2 continuous culture studies (Soder et al., 2013a,b), which is corroborated by data from the current study.

\section{Urinary Excretion of Nitrogenous Metabolites}

Treatment effects on urinary excretion of nitrogenous metabolites are presented in Table 8. Urinary concentration of creatinine tended $(P=0.09)$ to be greater in cows fed FLX than the CTRL diet. No dietary differences were observed for the urinary excretion of creatinine $($ mean $=92 \mathrm{mmol} / \mathrm{d})$, uric acid $($ mean $=$ $17.5 \mathrm{mmol} / \mathrm{d}$ ), allantoin $($ mean $=207 \mathrm{mmol} / \mathrm{d}$ ), and total PD (mean $=225 \mathrm{mmol} / \mathrm{d})$, and for the urinary PD-to-creatinine ratio $($ mean $=2.45)$. Trends for treatment by week interactions $(P \leq 0.10)$ were detected for urinary excretion of allantoin and PD, and PD-tocreatinine ratio. Flow of microbial $\mathrm{N}$ did not change when GFLX replaced orchardgrass herbage in our previous continuous culture fermentation studies (Soder et al., 2012, 2013a,b), which agree with urinary PD

Table 7. Least squares means for total nutrient intake, apparent total-tract digestibility of nutrients, and ruminal fermentation profile in Jersey cows grazing cool-season perennial herbage supplemented with a partial TMR plus $10 \%$ of the diet DM as ground corn-soybean meal mix ${ }^{1}$ $($ control diet $=\mathrm{CTRL})$ or ground flaxseed $($ flaxseed diet $=$ FLX)

\begin{tabular}{|c|c|c|c|c|c|c|}
\hline Item & \multicolumn{2}{|c|}{ Treatment (TRT) } & SEM & \multicolumn{3}{|c|}{$P$-value ${ }^{2}$} \\
\hline \multicolumn{7}{|l|}{ Intake, $\mathrm{kg} / \mathrm{d}$} \\
\hline $\mathrm{OM}$ & 14.7 & 15.3 & 0.47 & 0.41 & $<0.001$ & 0.84 \\
\hline $\mathrm{NDF}$ & 5.58 & 6.36 & 0.24 & 0.04 & 0.25 & 0.91 \\
\hline $\mathrm{ADF}$ & 3.33 & 3.91 & 0.15 & 0.02 & 0.42 & 0.81 \\
\hline DM & 63.0 & 61.5 & 0.58 & 0.10 & $<0.001$ & 0.48 \\
\hline $\mathrm{OM}$ & 65.7 & 63.9 & 0.55 & 0.04 & $<0.001$ & 0.86 \\
\hline $\mathrm{NDF}$ & 48.6 & 52.8 & 0.91 & $<0.01$ & $<0.001$ & 0.56 \\
\hline $\mathrm{ADF}$ & 43.6 & 44.8 & 1.11 & 0.41 & $<0.001$ & 0.91 \\
\hline $\mathrm{CP}$ & 62.6 & 62.6 & 1.00 & 0.98 & $<0.001$ & 0.29 \\
\hline \multicolumn{7}{|c|}{ Ruminal parameter ${ }^{4}$} \\
\hline $\mathrm{NH}_{3}-\mathrm{N}, \mathrm{mg} / \mathrm{dL}$ & 11.0 & 13.1 & 0.58 & 0.13 & $<0.001$ & 0.32 \\
\hline Isobutyrate & 1.04 & 1.02 & 0.02 & 0.55 & $<0.001$ & 0.15 \\
\hline Valerate & 1.14 & 1.13 & 0.07 & 0.95 & $<0.001$ & 0.49 \\
\hline Isovalerate & 0.76 & 0.71 & 0.04 & 0.44 & $<0.001$ & 0.52 \\
\hline A:P ratio & 4.06 & 3.68 & 0.10 & 0.05 & $<0.001$ & 0.14 \\
\hline
\end{tabular}

${ }^{1}$ The ground corn-soybean meal mix consisted (DM basis) of $61 \%$ ground corn plus $39 \%$ soybean meal.

${ }^{2}$ Significance was declared at $P \leq 0.05$ and trends at $0.05<P \leq 0.10$.

${ }^{3}$ Wk 4 (June 29 to July 5); wk 8 (July 27 to August 2); wk 12 (August 24 to 30); wk 16 (September 21 to 27).

${ }^{4} \mathrm{n}=5$ cows/treatment. 
Table 8. Least squares means for total $\mathrm{N}$ intake and urinary excretion of nitrogenous metabolites in Jersey cows grazing cool-season perennial herbage supplemented with a partial TMR plus $10 \%$ of the diet DM as ground corn-soybean meal mix ${ }^{1}$ (control diet $=$ CTRL) or ground flaxseed (flaxseed diet $=$ FLX)

\begin{tabular}{|c|c|c|c|c|c|c|}
\hline Item & \multicolumn{2}{|c|}{ Treatment (TRT) } & SEM & \multicolumn{3}{|c|}{$P$-value ${ }^{2}$} \\
\hline Total $\mathrm{N}$ intake, $\mathrm{g} / \mathrm{d}$ & 420 & 451 & 13.9 & 0.14 & $<0.001$ & 0.98 \\
\hline Urinary creatinine, $\mathrm{mmol} / \mathrm{d}$ & 91.7 & 92.0 & 1.01 & 0.86 & $<0.001$ & 0.30 \\
\hline Urinary uric acid, $\mathrm{mmol} / \mathrm{d}$ & 17.4 & 17.6 & 1.51 & 0.92 & $<0.001$ & 0.38 \\
\hline Urinary allantoin, $\mathrm{mmol} / \mathrm{d}$ & 207 & 206 & 5.13 & 0.90 & 0.05 & 0.10 \\
\hline Total urinary N, \% of $\mathrm{N}$ intake & 30.2 & 32.8 & 1.40 & 0.21 & $<0.001$ & 0.83 \\
\hline
\end{tabular}

${ }^{1}$ The ground corn-soybean meal mix consisted (DM basis) of $61 \%$ ground corn plus $39 \%$ soybean meal.

${ }^{2}$ Significance was declared at $P \leq 0.05$ and trends at $0.05<P \leq 0.10$.

${ }^{3}$ Wk 4 (June 29 to July 5); wk 8 (July 27 to August 2); wk 12 (August 24 to 30); wk 16 (September 21 to 27).

${ }^{4} \mathrm{PD}=$ purine derivatives (allantoin + uric acid).

excretion data observed herein. The amount of total $\mathrm{N}$ excreted in urine increased $(+25 \mathrm{~g} / \mathrm{d} ; P=0.01)$ with feeding FLX versus the CTRL diet. However, there was not a clear relationship between urinary $\mathrm{N}$ excretion and MUN or BUN concentration. While both urinary $\mathrm{N}$ excretion and BUN concentration (wk 4, 8, and 12; Table 4) increased with feeding FLX versus the CTRL diet, MUN decreased (wk 8 and 16; Table 4). Furthermore, increased urinary $\mathrm{N}$ excretion appears to be independent of $\mathrm{N}$ intake because no treatment effect was observed when urinary $\mathrm{N}$ excretion was expressed as a proportion of $\mathrm{N}$ intake (mean $=31.5 \%$; Table 8 ). It is important to note that there are uncertainties related to herbage DMI estimation as previously discussed, so total $\mathrm{N}$ intake data should be interpreted cautiously.

\section{CONCLUSIONS}

Our hypothesis that yields of milk and milk components would increase in response to enhanced dietary energy supply via GFLX was rejected. The second hypothesis was partially accepted as milk n-3 FA increased due to elevated intake of ALA in the FLX diet, but no effect was observed for milk cis-9,trans-11 18:2. Overall, results of the present study indicate that $10 \%$ GFLX can fully replace, on a DM basis, an equal amount of GRC-SBM mix without depressing yields of milk and milk components, with the added benefit of increased milk n-3 FA. However, costs and industry adoption of premiums for n-3 FA-enriched milk will determine the potential adoption of GFLX in pasturebased dairies. Further research in which grazing cows are supplemented with $>10 \%$ of GFLX in the diet DM is needed to assess the effect of ALA intake on milk trans-11 18:1 and cis-9,trans-11 18:2.

\section{ACKNOWLEDGMENTS}

Partial funding was provided by the New Hampshire Agricultural Experiment Station (Durham, NH; Scientific Contribution Number 2800). This work was further supported by the USDA-National Institute of Food and Agriculture-Organic Agriculture Research and Extension Initiative (Project Number NHW-2011-01950; Project Accession Number 226410) and Hatch Multistate NC-2042 (Project Number NH00616-R; Project Accession Number 1001855). The authors thank Nancy L. Whitehouse (University of New Hampshire) for support through sample collection, technical assistance, and statistical guidance. The authors give special thanks to the University of New Hampshire students Kelly O'Connor, Alex Catalano, Milena Lima, Monica Stimmel, Cassie Biron, Kate Homan, Caren Ghedini, and Coleen Chapman for help during sample collection. Gratitude is extended to the University of New Hampshire Burley-Demeritt Organic Dairy Research Farm manager Nicole Guindon and her staff (Mark Dill and Shane Devanney) for animal care and overall research support.

\section{REFERENCES}

Aikman, P. C., C. K. Reynolds, and D. E. Beever. 2008. Diet digestibility, rate of passage, and eating and rumination behavior of Jersey and Holstein cows. J. Dairy Sci. 91:1103-1114.

AOAC. 1990. Official Methods of Analysis. 15th ed. AOAC, Arlington, VA.

Bargo, F., L. D. Muller, E. S. Kolver, and J. E. Delahoy. 2003. Invited review: Production and digestion of supplemented dairy cows on pasture. J. Dairy Sci. 86:1-42.

Bauman, D. E., and J. M. Griinari. 2001. Regulation and nutritional manipulation of milk fat: low-fat milk syndrome. Livest. Prod. Sci. $70: 15-29$

Benbrook, C. M., D. R. Davis, B. J. Heins, M. A. Latif, C. Leifert, L. Peterman, G. Butler, O. Faergeman, S. Abel-Caines, and M. 
Baranski. 2018. Enhancing the fatty acid profile of milk through forage-based rations, with nutrition modeling of diet outcomes. Food Sci. Nutr. 6:681-700

Binnerts, W. T., A. T. Van't Klooster, and A. M. Frens. 1968. Soluble chromium indicator measured by atomic absorption in digestion experiments. Vet. Rec. 82:470-472.

Boufaied, H., P. Y. Chouinard, G. F. Tremblay, H. V. Petit, R. Michaud, and G. Belanger. 2003. Fatty acids in forages. I. Factors affecting concentrations. Can. J. Anim. Sci. 83:501-511.

Brito, A. F., K. J. Soder, P. Y. Chouinard, S. F. Reis, S. Ross, M. D. Rubano, and M. D. Casler. 2017. Production performance and milk fatty acid profile in grazing dairy cows offered ground corn or liquid molasses as the sole supplemental nonstructural carbohydrate source. J. Dairy Sci. 100:8146-8160.

Brossillon, V., S. F. Reis, D. C. Moura, J. G. B. Galvão Jr, A. S. Oliveira, C. Côrtes, and A. F. Brito. 2018. Production, milk and plasma fatty acid profile, and nutrient utilization in Jersey cows fed flaxseed oil and corn grain with different particle size. J. Dairy Sci. 101:2127-2143.

Cargill. 2014. Study shows consumers want more omega-3. Cargill's FATitudes, Minneapolis, MN. Accessed Jul. 2, 2018. https://www .cargill.com/news/releases/2014/NA31701258.jsp.

Chen, X. B., Y. K. Chen, M. F. Franklin, E. R. Ørskov, and W. J. Shand. 1992. The effect of feed intake and body weight on purine derivative excretion and microbial protein supply in sheep. J. Anim. Sci. 70:1534-1542.

Chilliard, Y., A. Ferlay, R. Mansbridge, and M. Doreau. 2000. Ruminant milk fat plasticity: Nutritional control of saturated, polyunsaturated, trans and conjugated fatty acids. Ann. Zootech. 49:181-205.

Chizzotti, M. L., S. C. Valadares Filho, R. F. D. Valadares, F. H. M Chizzotti, and L. O. Tedeschi. 2008. Determination of creatinine excretion and evaluation of spot urine sampling in Holstein cattle. Livest. Sci. 113:218-225.

Collomb, M., H. Sollberger, U. Bütikofer, R. Sieber, W. Stoll, and W. Schaeren. 2004. Impact of a basal diet of hay and fodder beet supplemented with rapeseed, linseed and sunflowerseed on the fatty acid composition of milk fat. Int. Dairy J. 14:549-559.

Connor, W. E. 2000. Importance of n-3 fatty acids in health and disease. Am. J. Clin. Nutr. 71(Suppl.):171S-175S.

Dhiman, T. R., L. D. Satter, M. W. Pariza, M. P. Galli, K. Albright, and M. X. Tolosa. 2000. Conjugated linoleic acid (CLA) content of milk from cows offered diets rich in linoleic and linolenic acid. J. Dairy Sci. 83:1016-1027.

Dillard, S. L., A. N. Hafla, M. D. Rubano, R. C. Stout, A. F. Brito, and K. J. Soder. 2016. Evaluation of a rising plate meter for use in multispecies swards. Agric. Environ. Lett. 1:160032.

Dilzer, A., and Y. Park. 2012. Implication of conjugated linoleic acid (CLA) in human health. Crit. Rev. Food Sci. Nutr. 52:488-513.

Ferlay, A., M. Doreau, C. Martin, and Y. Chilliard. 2013. Effects of incremental amounts of extruded linseed on the milk fatty acid composition of dairy cows receiving hay or corn silage. J. Dairy Sci. 96:6577-6595.

Fievez, V., E. Colman, J. M. Castro-Montoya, I. Stefanov, and B. Vlaeminck. 2012. Milk odd- and branched-chain fatty acids as biomarkers of rumen function-An update. Anim. Feed Sci. Technol. 172:51-65.

Flowers, G., S. A. Ibrahim, and A. A. AbuGhazaleh. 2008. Milk fatty acid composition of grazing dairy cows when supplemented with linseed oil. J. Dairy Sci. 91:722-730.

Gaines, W. L., and F. A. Davidson. 1923. Relation between percentage fat content and yield of milk. Univ. Illinois Agric. Exp. Stn. Bull. 245. Univ. Illinois, Urbana.

Gonthier, C., A. F. Mustafa, R. Berthiaume, H. V. Petit, R. Martineau, and D. R. Ouellet. 2004. Effects of feeding micronized and extruded flaxseed on ruminal fermentation and nutrient utilization by dairy cows. J. Dairy Sci. 87:1854-1863.

Gustafsson, A. H., and D. C. Palmquist. 1993. Diurnal variation of rumen ammonia, serum urea, and milk urea in dairy cows at high and low yields. J. Dairy Sci. 76:475-484.
Hafla, A. N., K. J. Soder, A. F. Brito, R. Kersbergen, A. F. Benson, H. Darby, M. D. Rubano, S. L. Dillard, J. Kraft, and S. F. Reis. 2018. Effects of seasonal variation and winter supplementation of ground whole flaxseed on milk fatty acid composition of dairy cows in organic farms in the northeastern United States. Prof. Anim. Sci. 34:397-409.

Hafla, A. N., K. J. Soder, A. F. Brito, R. Kersbergen, A. F. Benson, H. M. Darby, M. D. Rubano, and S. F. Reis. 2016. Case study: Feeding strategy and pasture quality relative to nutrient requirements of dairy cows in the northeastern United States. Prof. Anim. Sci. $32: 523-530$

Hellwing, A. L. F., P. Lund, M. R. Weisbjerg, F. W. Oudshoorn, L. Munksgaard, and T. Kristensen. 2015. Comparison of methods for estimating herbage intake in grazing dairy cows. Livest. Sci. 176:61-74.

Huhtanen, P., K. Kaustell, and S. Jaakkola. 1994. The use of internal markers to predict total digestibility and duodenal flow of nutrients in cattle given six different diets. Anim. Feed Sci. Technol. 48:211-227.

Kolver, E. S. and L. D. Muller. 1998. Performance and nutrient intake of high producing Holstein cows consuming pasture or a total mixed ration. J. Dairy Sci. 81:1403-1411.

Lerch, S., A. Ferlay, D. Pomiès, B. Martin, J. A. A. Pires, and Y Chilliard. 2012a. Rapeseed or linseed supplements in grass-based diets: Effects on dairy performance of Holstein cows over two consecutive lactations. J. Dairy Sci. 95:1956-1970.

Lerch, S., A. Ferlay, K. J. Shingfield, B. Martin, D. Pomiès, and Y. Chilliard. 2012b. Rapeseed or linseed supplements in grass-based diets: Effects on milk fatty acid composition of Holstein cows over two consecutive lactations. J. Dairy Sci. 95:5221-5241.

Lerch, S., K. J. Shingfield, A. Ferlay, A. Vanhatalo, and Y. Chilliard. 2012c. Rapeseed or linseed in grass-based diets: Effects on conjugated linoleic and conjugated linolenic acid isomers in milk fat from Holstein cows over 2 consecutive lactations. J. Dairy Sci. 95:7269-7287.

Licitra, G. T. M. Hernandez, and P. J. Van Soest. 1996. Standardization of procedures for nitrogen fractionation of ruminant feeds. Anim. Feed Sci. Technol. 57:347-358.

Lodge-Ivey, S. L., J. Browne-Silva, and M. B. Horvath. 2009. Technical note: Bacterial diversity and fermentation end products in rumen fluid samples collected via oral lavage or rumen cannula. J. Anim. Sci. 87:2333-2337.

Loor, J. J., K. Ueda, A. Ferlay, Y. Chilliard, and M. Doreau. 2004 Biohydrogenation, duodenal flow, and intestinal digestibility of trans fatty acids and conjugated linoleic acids in response to dietary forage:concentrate ratio and linseed oil in dairy cows. J. Dairy Sci. 87:2472-2485.

Mayes, R. W., and H. Dove. 2000. Measurement of dietary nutrient intake in free-ranging mammalian herbivores. Nutr. Res. Rev. 13:107-138.

McCrorie, T. A., E. M. Keaveney, J. M. W. Wallace, N. Binns, and M. B. E. Livingstone. 2011. Human health effects of conjugated linoleic acid from milk and supplements. Nutr. Res. Rev. 24:206-227.

Mir, P. S., S. Bittman, D. Hunt, T. Entz, and B. Yip. 2006. Lipid content and fatty acid composition of grasses sampled on different dates through the early part of the growing season. Can. J. Anim. Sci. 86:279-290.

NRC. 2001. Nutrient Requirements of Dairy Cattle. 7th rev. ed. Natl Acad. Sci., Washington, DC.

Oltner, R., and H. Wiktorsson. 1983. Urea concentrations in milk and blood as influenced by feeding varying amounts of protein and energy to dairy cows. Livest. Prod. Sci. 10:457-467.

Orth, R. 1992. Sample Day and Lactation Report. DHIA 200 FactSheet A-2. Mid-States DRPC, Ames, IA.

Pereira, A. B. D., A. F. Brito, L. L. Townson, and D. H. Townson. 2013. Assessing the research and education needs of the organic dairy industry in the northeastern United States. J. Dairy Sci. 96:7340-7348.

Pereira, A. B. D., N. L. Whitehouse, K. M. Aragona, C. S. Schwab, S. F. Reis, and A. F. Brito. 2017. Production and nitrogen utilization 
in lactating dairy cows fed ground field peas with or without ruminally protected lysine and methionine. J. Dairy Sci. 100:6239-6255.

Petit, H. V. 2010. Milk yield and milk composition of dairy cows fed flaxseed: A review. Can. J. Anim. Sci. 90:115-127.

Petit, H. V., and C. Côrtes. 2010. Milk production and composition, milk fatty acid profile, and blood composition of dairy cows fed whole or ground flaxseed in the first half of lactation. Anim. Feed Sci. Technol. 158:36-43.

Rego, O. A., S. P. Alves, L. M. S. Antunes, H. J. D. Rosa, C. F. M. Alfaia, J. A. M. Prates, A. R. J. Cabrita, A. J. M. Fonseca, and R. J. B. Bessa. 2009. Rumen biohydrogenation-derived fatty acids in milk fat from grazing dairy cows supplemented with rapeseed, sunflower, or linseed oils. J. Dairy Sci. 92:4530-4540.

Resende, T. L., J. Kraft, K. J. Soder, A. B. D. Pereira, D. E. Woitschach, R. B. Reis, and A. F. Brito. 2015. Incremental amounts of ground flaxseed decrease milk yield but increase n-3 fatty acids and conjugated linoleic acids in dairy cows fed high-forage diets. J. Dairy Sci. 98:4785-4799.

Rico, D. E., and K. J. Harvatine. 2013. Induction of and recovery from milk fat depression occurs progressively in dairy cows switched between diets that differ in fiber and oil concentration. J. Dairy Sci. 96:6621-6630.

Roseler, D. K., J. D. Ferguson, C. J. Sniffen, and J. Herrema. 1993 Dietary protein degradability effects on plasma and milk urea nitrogen and milk nonprotein nitrogen in Holstein cows. J. Dairy Sci. 76:525-534.

Rosenthal, H. L. 1955. Determination of urea in blood and urine with diacetyl monoxime. Anal. Chem. 27:1980-1982.

Scholljegerdes, E. J., and S. Kronberg. 2010. Effect of supplemental ground flaxseed fed to beef cattle grazing summer native range on the northern Great Plains. J. Anim. Sci. 88:2108-2121.

Soder, K. J., A. F. Brito, and M. D. Rubano. 2013a. Short communication: Effect of oilseed supplementation of an herbage diet on ruminal fermentation in continuous culture. J. Dairy Sci. 96:2551-2556.
Soder, K. J., A. F. Brito, and M. D. Rubano. 2013b. Effect of supplementing orchardgrass herbage with a total mixed ration or flaxseed on fermentation profile and bacterial protein synthesis in continuous culture. J. Dairy Sci. 96:3228-3237.

Soder, K. J., A. F. Brito, M. D. Rubano, and C. J. Dell. 2012. Effect of incremental flax supplementation of an herbage diet on methane output and ruminal fermentation in continuous culture. J. Dairy Sci. 95:3961-3969.

Sterk, A., B. E. O. Johansson, H. Z. H. Taweel, M. Murphy, A. M. van Vuuren, W. H. Hendriks, and J. Dijkstra. 2011. Effects of forage type, forage to concentrate ratio, and crushed linseed supplementation on milk fatty acid profile in lactating dairy cows. J. Dairy Sci. 94:6078-6091.

Sukhija, P. S., and D. L. Palmquist. 1988. Rapid method for determination of total fatty acid content and composition of feedstuffs and feces. J. Agric. Food Chem. 36:1202-1206.

Ward, A. T., K. M. Wittenberg, and R. Przybylski. 2002. Bovine milk fatty acid profiles produced by feeding diets containing solin, flax and canola. J. Dairy Sci. 85:1191-1196.

White, S. L., J. A. Bertrand, M. R. Wade, S. P. Washburn, J. T. Green Jr., and T. C. Jenkins. 2001. Comparison of fatty acid content of milk from Jersey and Holstein cows consuming pasture or a total mixed ration. J. Dairy Sci. 84:2295-2301.

Wildman, E. E., G. M. Jones, P. E. Wagner, R. L. Boman, H. F. Troutt Jr., and T. N. Lesch. 1982. Dairy cow body condition scoring system and its relationship to selected production characteristics. J. Dairy Sci. 65:495-501.

Williams, C. H., D. J. David, and O. Iismaa. 1962. The determination of chromic oxide in faeces samples by atomic absorption spectrophotometry. J. Agric. Sci. 59:381-385.

Williams, C. M. 2000. Dietary fatty acids and human health. Ann. Zootech. 49:165-205. 